\title{
KNOWLEDGE TRANSFER FROM DETAILED 3-D CFD CODES TO SYSTEM SIMULATION TOOLS - CCV MODELING IN SI ENGINE
}

\section{OLDR̆ICH VÍTEK, JAN MACEK}

Czech Technical University in Prague, Department of Automotive, Combustion Engine and Railway Engineering, Technická 4, CZ-16607 Prague 6, Czech Republic, Tel.: +420224352507, Fax: +420224352500, E-mail: oldrich.vitek@fs.cvut.cz

\section{CHRISTOPH POETSCH, REINHARD TATSCHL}

AVL LIST GmbH, Advanced Simulation Technologies, Graz, Austria, E-mail: reinhard.tatsch|@avl.com

\section{ABSTRACT}

The paper deals with CCV knowledge transfer from reference data (either experiments or 3-D CFD data) into system simulation SW tools (based on 0-D/1-D CFD). It was verified that CCV phenomenon can be modeled by means of combustion model perturbations. The proposed methodology consists of two major steps. First, individual cycle data have to be matched with the 0-D/1-D model, i.e., combustion model parameters are varied to achieve the best possible match of in-cylinder pressure traces. Second, the combustion model parameters (obtained in previous step) are statistically evaluated to obtain PDFs and crosscorrelations. Then such information is imposed to the 0-D/1-D tool to mimic pressure traces CCV. Good correspondence with the reference data is achieved only if both PDFs and cross-correlations are imposed simultaneously.

Different engine operating points were evaluated to draw some general conclusions in terms of CCV. It was confirmed that turbulence properties and initial flame kernel development are the dominant factors. However, these factors are neither independent nor random - they seem to be correlated. Operating points with high CCV are more organized in terms of the statistics - they exhibit strong cross-correlations of combustion model parameters.

KEYWORDS: CYCLE-TO-CYCLE VARIATIONS, STATISTICAL ANALYSIS, PDFS, CROSS-CORRELATION, KNOWLEDGE TRANSFER, O-D/1-D CFD

\section{SHRNUTÍ}

Článek se zabývá přenosem znalostí ohledně mezicyklové variability z referenčních dat (bud' experimenty nebo 3-D CFD data) do SW nástrojů pro systémovou simulaci (založeno na 0-D/1-D CFD). Bylo ověřeno, že mezicyklovou variabilitu Ize modelovat pomocí fluktuací parametrů modelu hoření. Navržená metoda se skládá ze dvou kroků. Zaprvé, data z jednotlivých cyklů jsou kalibrována s 0-D/1-D modelem, tj. parametry modelu hoření jsou měněny tak, aby bylo dosaženo nejlepší možné shody průběhu tlaku ve válci. Zadruhé, parametry modelu hoření (získané v předchozím kroku) jsou statisticky zpracovány pro získání hustot pravděpodobnosti a vzájemných korelací. Pak je tato informace vnucena do 0-D/1-D nástroje pro napodobení mezicyklové variability tlaku ve válci. Dobrá shoda s referenčními daty je dosažena pouze pokud je jak hustota pravděpodobnosti, tak vzájemná korelace použita současně.

Rủzné pracovní body motoru byly vyhodnoceny pro formulaci obecných závěrů z hlediska mezicyklové variace. Bylo ověřeno, že vlastnosti turbulence a počáteční vývoj jádra plamene jsou dominantní parametry. Avšak tyto parametry nejsou ani nezávislé ani náhodné - zdá se, že jsou vzájemně provázané. Pracovní body s velkou mezicyklovou variabilitou jsou ze statistického pohledu více organizované - vykazují silnou vzájemnou korelaci parametrů modelu hoření.

KLIČOVÁ SLOVA: MEZICYKLOVÁ VARIABILITA, STATISTICKÁ ANALÝZA, HUSTOTA PRAVDĔPODOBNOSTI, VZÁJEMNÁ KORELACE, PŘENOS INFORMACI, 0-D/1-D CFD 


\section{INTRODUCTION}

The operation of spark-ignition (SI) engines is characterized by a non-repeatability of the instantaneous combustion rate of the individual engine cycles at nominally identical engine operating parameters, commonly referred to as cyclic combustion variability. The CCV phenomenon is closely related to SI engine operation and it is important to study its influence on engine performance or engine external components (e.g., turbocharger, exhaust aftertreatment system). For CCV amplitudes (measured in terms of standard deviation of IMEP, normalized by the mean value) exceeding $5 \%$, individual cycles behave very differently from the statistically-averaged mean engine cycle. Hence, it can have a negative influence on engine operation.

The phenomenon of cycle-to-cycle variations of internal combustion engine is well known for many decades, hence the researchers have been dealing with it for a long time. However, the origin and nature of CCV is still not well understood. Spark ignition engines seem to be more affected by this effect, though compression ignition engines also feature certain level of CCV. It is obvious that CCV leads to lower engine efficiency while increasing production of pollutants. This is not desired, hence a lot of effort is made to minimize CCV effects. The main sources of CCV have been identified: in-cylinder turbulence, variations in mixture composition (air excess and/or EGR), initial flame kernel development, variations of ignition/injection system, etc. Based on that, combustion process is the most important phase of ICE cycle when dealing with CCV - this is certainly true, however motored regimes also exhibit CCV. It seems that there are differences (in terms of (CV) among the engines - they are caused by the design (direct/indirect injection, liquid/gaseous fuel, ignition system, etc). This makes systematic comparison even more difficult as every engine has its unique features.

In view of the increasingly stringent legislative demands on fuel consumption, $\mathrm{CO}_{2}$ production, and pollutant emissions, it becomes mandatory to be able to predict and control individual engine cycles, and thus to address the occurrence and the impact of CCV on fuel consumption and other important ICE output parameters (e.g., knocking, pollutant formation). Being able to predict CCV in the early engine design phase is essential to exploit the full potential of promising new SI engine technologies, such as e.g. direct-injection, down-sizing, extreme charging, etc. under real operation. This leads to an increased need to make such capabilities available in system simulation tools which are increasingly used in the engine development and optimization process.

The main objective of the paper is to develop and to verify a methodology which enables knowledge transfer from reference data (3-D CFD data or experimental ones) to system simulation SW tools (usually based on 0-D/1-D CFD approach) while the main focus is put on modelling of CCV.

\section{MATHEMATICAL MODEL}

The DI SI engine configuration adopted for the activities within the present work is based on the AVL Single Cylinder Research Engine (SCRE), Figure 1, which is a fully flexible single-cylinder base engine configuration that can be equipped with a large variety of cylinder heads, valve trains and injection systems. In its adopted configuration, the engine had a nominal compression ratio of 11.5 and was equipped with a four-valve cylinder head and a side mounted gasoline injector with double injection capability. It was equipped with intake and exhaust cam-phasers allowing flexible valve timing and valve overlap strategies. Main engine parameters are summarized in Table 1.

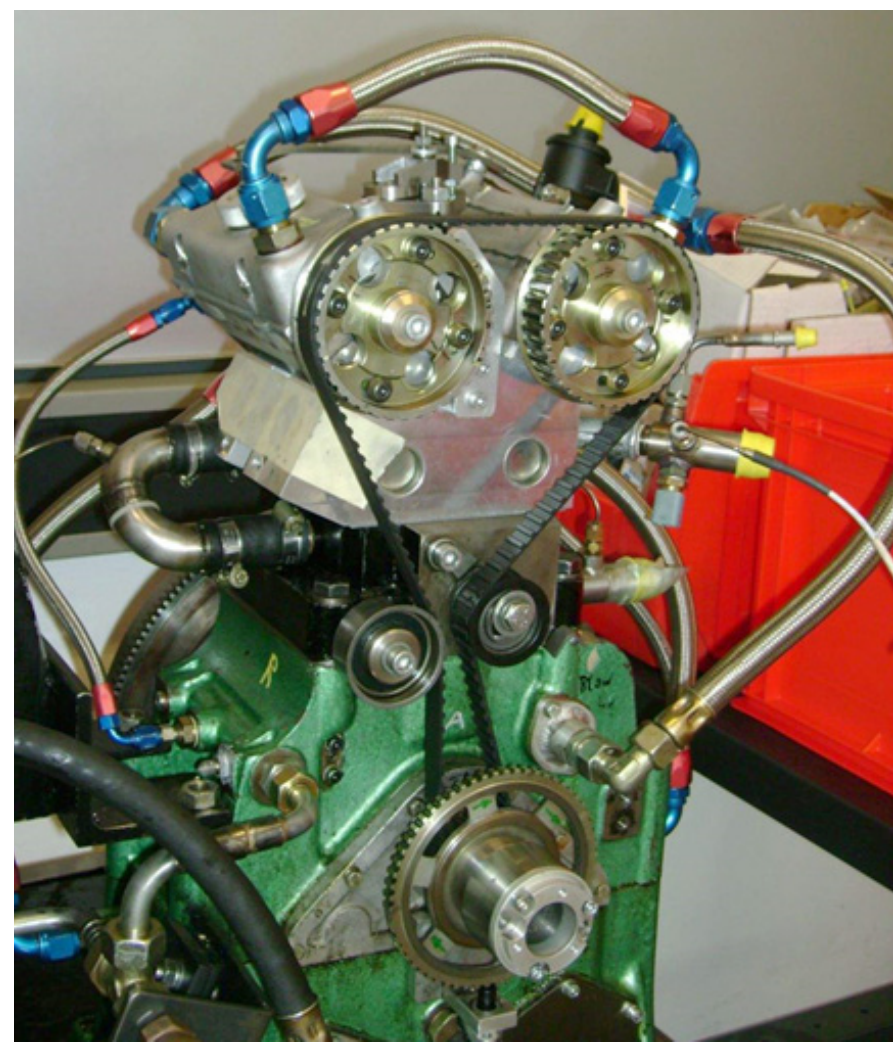

FIGURE 1: Target engine - AVL Single Cylinder Research Engine. OBRÁZEK 1: Cílový motor - zkušební jednoválec od AVL.

TABLE 1: Main engine parameters.

TABULKA 1: Hlavní parametry motoru.

\begin{tabular}{lcc}
\hline Engine Parameter & Unit & Value \\
\hline Bore-to-Stroke Ratio & {$[1]$} & 1.0 \\
\hline Compression Ratio & {$[1]$} & 11.5 \\
\hline Charging & & Naturally Aspirated \\
\hline Fuel & & Gasoline (ON 95) \\
\hline Number of Intake Valves & 2 (phasing) \\
\hline Number of Exhaust Valves & 2 (phasing) \\
\hline
\end{tabular}


A full 0-D/1-D cylinder/flow model of the entire engine was set in order to properly model the tested engine configuration including all intake and exhaust ductworks and thus to provide proper 1-D pressure, temperature and mass initial conditions in the combustion chamber at the time of inlet-valve closure. The model consists of the engine cylinder itself plus all relevant pipes and volumes in the intake and exhaust line. Parameterization of the flow coefficients and other relevant parameters is achieved on the basis of the measured/GCA processed data at selected monitoring locations of the system. When dealing with system simulation, a standard approach is to apply 0-D/1-D tools (e.g., [13]) which provide relatively fast computations while being able to keep a sound physical basis. They are suitable for modeling of the whole system, e.g., all important thermodynamic parts of the engine. That is why it is important to be able to impose CCV phenomenon into those tools to understand its influence at a system level. That is why it was decided to model (in tool [13]) the whole experimental setup of the target engine.

It is clear that the most important model, which influences CCV in ICE, is a combustion model. The in-cylinder combustion is modeled by means of the fractal combustion model, which is the physically based, predictive combustion model. This model takes into account both engine configuration (e.g. combustion chamber geometry) as well as operating parameters (e.g. turbulence characteristics, ignition timing, charge state at IVC, ...) on a 0-D basis. The fractal combustion model is of the type of flamelet models. In these models, the flame front is considered an infinitely thin area, which is highly wrinkled due to the effects of turbulent eddies of different length scales. Therefore, the combustion model required as an input the incylinder turbulence level. More detailed description can be found in $[1,2,3,4,9]$.

TABLE 2: Main parameters of all considered engine operating points.

TABULKA 2: Hlavní parametry všech uvažovaných pracovních bodů.

\begin{tabular}{lccccccc} 
Engine Par. & Unit & LP2690 & LP2735 & LP2504 & LP2610 & LP2290 & LP2299 \\
Engine Speed & {$[\mathrm{rpm}]$} & 3000 & 3000 & 2000 & 2000 & 1250 & 1250 \\
\hline CCV Level & & Low & High & Low & High & Low & High \\
\hline Valve Overlap & {$[\mathrm{degCA}]$} & 12 & 53 & 0 & 63 & 0 & 34 \\
\hline Tot. EGR at IVCl & {$[\%]$} & 12 & 29 & 13 & 34 & 9 & 22 \\
\hline Exp. IMEP & {$[\mathrm{bar}]$} & 2.30 & 2.31 & 2.85 & 3.06 & 2.86 & 3.12 \\
\hline Ignition Timing & {$[\mathrm{degCA}]$} & -16 & -29 & -17 & -30 & -17 & -26 \\
\hline COV: Exp. IMEP & {$[\%]$} & 1.73 & 2.99 & 1.53 & 2.62 & 1.54 & 2.69
\end{tabular}
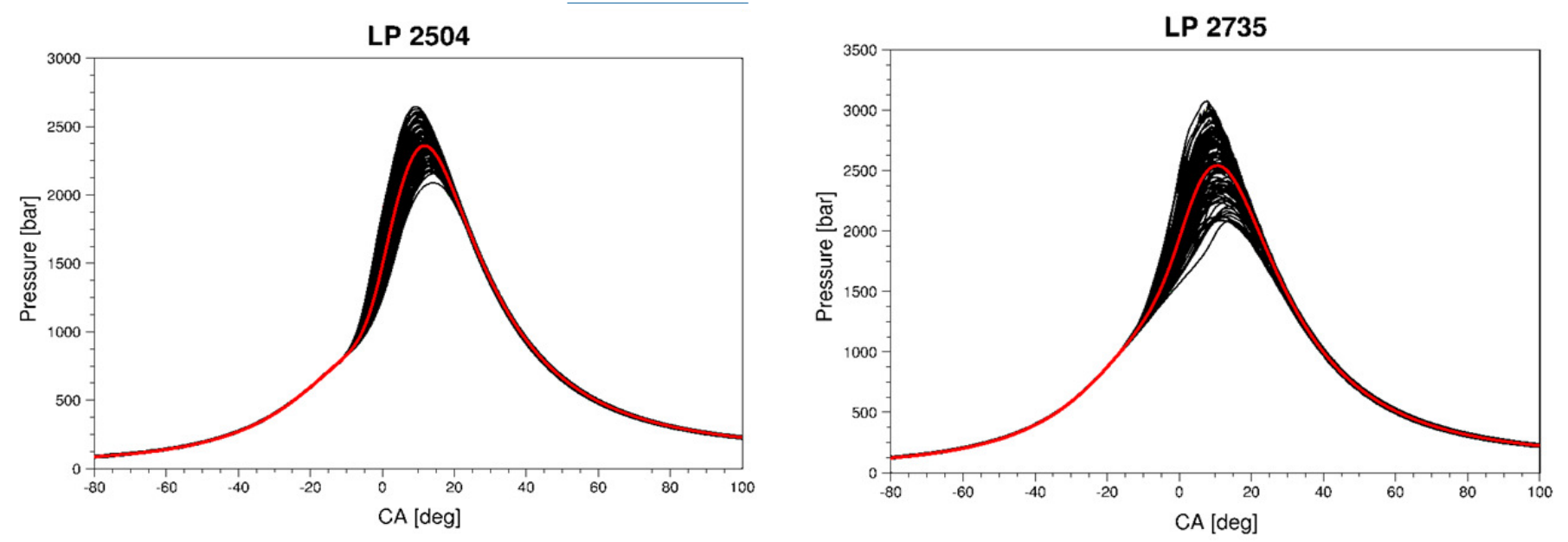

FIGURE 2: Detail cylinder pressure traces for 2 engine operating points (labeling of operating points corresponds to Table 2); black color: cycle-resolved data, red color: cycle-averaged data.

OBRÁZEK 2: Detailní průběhy tlaku ve válci pro 2 vybrané pracovní body motoru (označení pracovních bodů odpovídá Tabulce 2); černá barva: data z jednotlivých cyklů motoru, červená barva: průměrný oběh. 


\section{AVAILABLE DATA FROM 3-D CFD}

This section deals with description of available reference data which contain CCV information. Such data are usually obtained from measurements. However, it is possible to predict such data on a sound basis when performing multicycle LES simulations. This was successfully done in the past by different research teams dealing with advanced 3-D CFD calculations - c.f. $[5,6,7,8]$. However, the quality of LES simulations with respect to quantitative prediction is still not at optimal level - on the other hand, qualitative trends are usually very well predicted by that approach. Hence, the recommended case is a combination of both - experimental data, which usually contain global information, and 3-D CFD data (typically based on LES approach), which can provide also detailed local information.
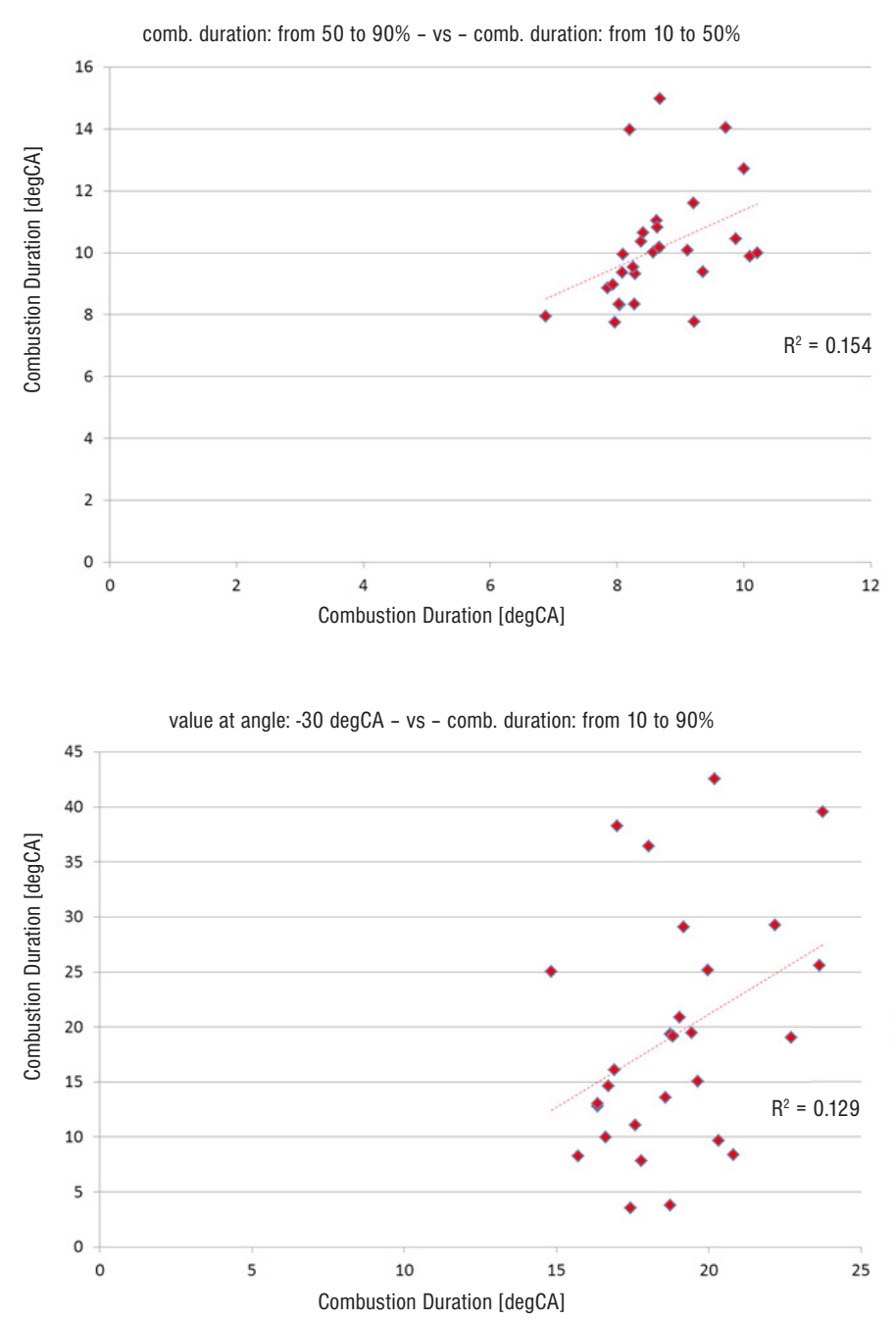

This was also the case of the presented results - both experimental data and detailed 3-D CFD ones (based on multi-cycle LES calculations - c.f. $[5,6])$ were available. All these data sets are referenced in the following text of the paper as the reference data. Regarding the considered operating points of the target engine, they are summarized in Table 2 . These points were selected on purpose as they represent significantly different cases in terms of CCV - three of them correspond to low CCV cases while the remaining ones exhibit high CCVs. Hence, enough information was available in terms of CCV knowledge which is supposed to be transferred into system simulation tools based on 0-D/1-D CFD approach. Such information consists of both global/integral data, which characterize a thermodynamic status of the whole combustion chamber (c.f. Figure 2 and $1^{\text {st }}$ row of Figure 3), and detailed local data (c.f. last row of Figure 3).
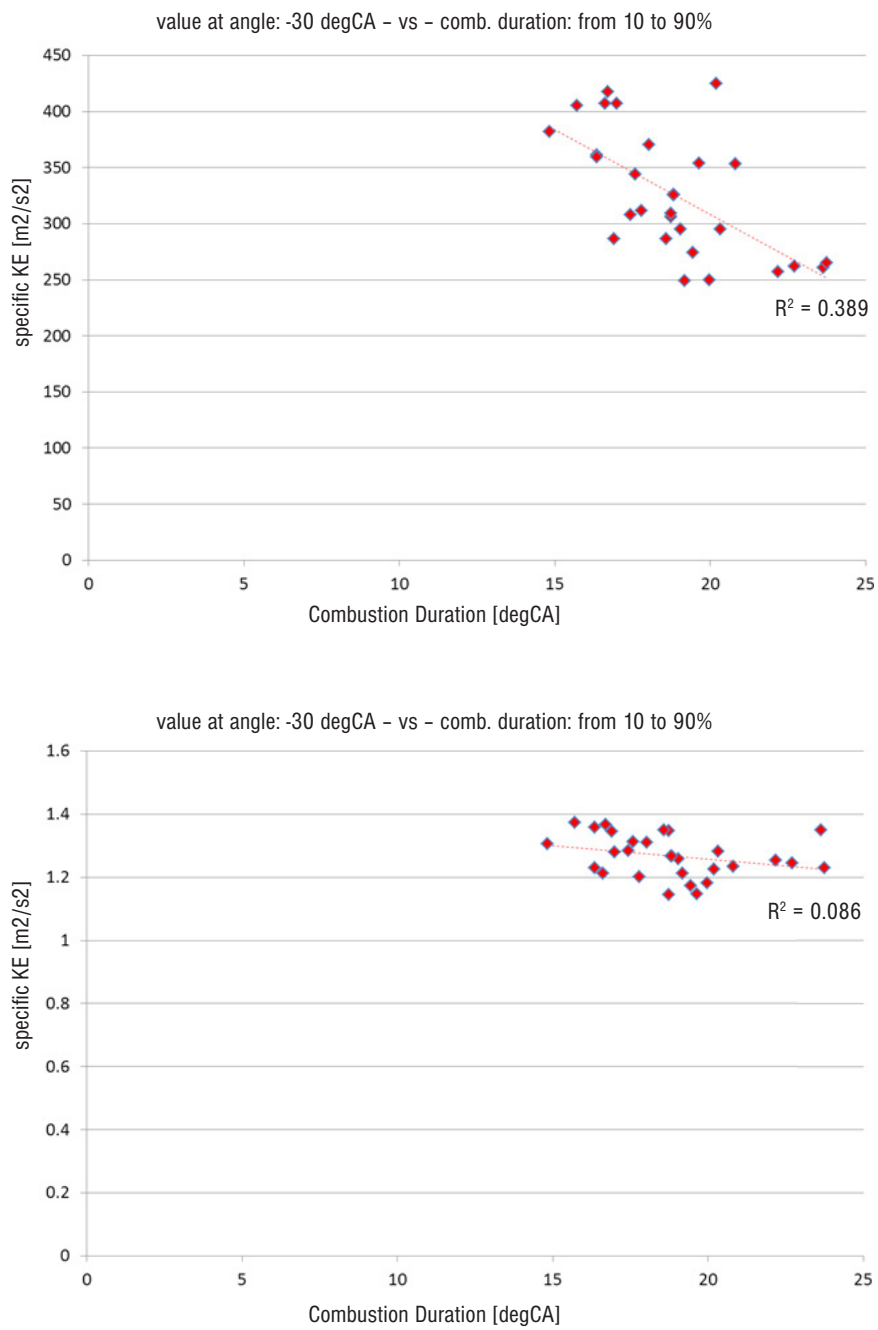

FIGURE 3: Example of available integral data from 3-D CFD for the case of LES multi-cycle calculations of operating point LP 2735 (labeling corresponds to Table 2) - linear trend including square of correlation coefficient is shown.

OBRÁZEK 3: Príklad integrálních dat, která jsou k dispozici z 3-D CFD pro prípad LES výpočtu mnoha pracovních oběhů pracovního bodu LP 2735 (označení odpovídá Tabulce 2) - je zobrazen také lineární trend včetně kvadrátu korelačního koeficientu. 


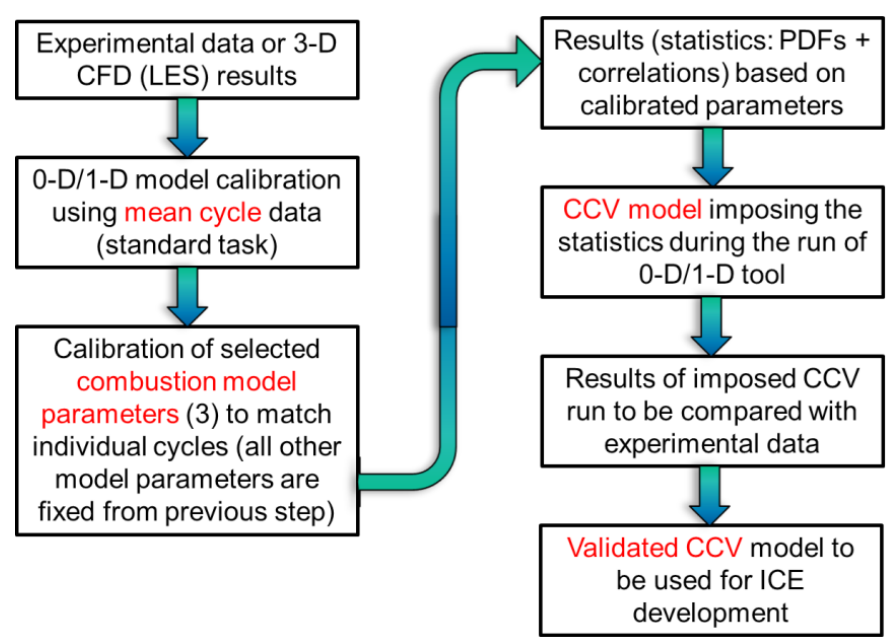

FIGURE 4: Workflow when performing CCV knowledge transfer from 3-D CFD to $0-1 / 1-D$ system simulation SW tools.

OBRÁZEK 4: Postup pro přenos informací ohledně mezyciklové variability z 3-D CFD do systémových nástrojů založených na 0-D/1-D.

The data shown in Figure 3 correspond to multi-cycle LES calculations including combustion phase for the case of the target engine - more than 30 consecutive cycles were calculated and analyzed. The data show significant CCV of combustion parameters, global values and local ones (e.g., at spark plug location) as well. As the target engine is a singlecylinder engine with periodic boundary conditions (imposed by user while being based on averaged crank-angle-resolved experimental data), the CCV comes from non-linear interaction of turbulence with propagating flame. Hence, it confirms that turbulence and combustion are the main sources of CCV. Based on that, perturbation of combustion model parameters in system simulation SW tools is supposed to be a reasonable approach for correct CCV modelling in those tools.

\section{METHODOLOGY OF CCV MODELLING IN O-D/1-D CFD SW TOOL}

As the reference data clearly show that there is non-negligible CCV (c.f. section Available Data) and the main focus of the paper is the CCV phenomenon, the information regarding CCV needs to be transferred into 0-D/1-D CFD SW tool. It is obvious that such tool cannot predict that as the CCV phenomenon is related to local 3-D effects (e.g., non-linear interaction between turbulence and flame). Hence, there is a need to develop methodology which enables knowledge transfer from reference data (typically 3-D CFD data) to 0-D/1-D SW tools while preserving important statistics of CCV. The methodology is based on the scheme of Figure 4 and papers $[9,10]$, moreover it is briefly described in the following subsections.

\subsection{AVERAGE CYCLE CALIBRATION}

As the target engine (c.f. Table 1) is a single cylinder engine, the intake and exhaust system is relatively simple. The engine is equipped with variable valve timing (VVT) and a direct-injection combustion system. The latter fact brings special challenges to modeling due to the more complex geometry of the DI piston bowl. All important information regarding geometry (including valve train properties) was well known and it was applied consistently in both 0-D/1-D tool [13] and 3-D CFD one [12]. Based on that, the model was calibrated in detail to match with experimental data for the average cycle of all considered operating points (c.f. Table 2).

The standard calibration procedure included the following steps:

1. High Pressure Analysis

2. Calibration of Gas Exchange

3. Calibration of Turbulence based on CFD Data

Ad 1: The high pressure analysis calculates the in-cylinder heat release based on energy balance including submodels for heat transfer and blow-by. For the present study a 2-zone analysis was selected, as it matches the thermodynamic approach of the fractal combustion model and therefore allows a direct comparison of ROHR. The first step also includes calibration of heat transfer and blow-by model as well as the adaption of the motored pressure curve.

Ad 2: The physical modeling of the combustion relies on the estimation of the in-cylinder turbulence level which predominantly depends on the intake and exhaust processes. Therefore it is not enough to focus on the high pressure cycle. The model uses as an input the analyzed ROHR from step 1 . Focus of the calibration is to match measured mass flow, intake/ exhaust temperatures from various sensor position and finally in-cylinder pressure traces.

Ad 3: As soon as gas exchange process is correctly predicted, it is possible to calibrate the turbulence model, which used intake and exhaust mass flow as an input. Target function for the matching is the TKE characteristics from the 3-D CFD [12] results. As shown in Figure 5, a good agreement of TKE is achieved, especially during the relevant combustion phase $(-20$ to +50 $\operatorname{deg}(A)$. One can also see that the intake peak is over-predicted in the 0-D model. Still, if we emphasize that the high flow velocity at IVC is a major source of in-cylinder turbulence, the position of the intake peak would need to occur near IVC which is the case in the 0-D/1-D model. The dissipation of turbulent kinetic energy during compression as well as the increase around firing TDC are well in line with the 3-D results. Especially at these low engine speeds, the results of the 0-D model are reasonable. 


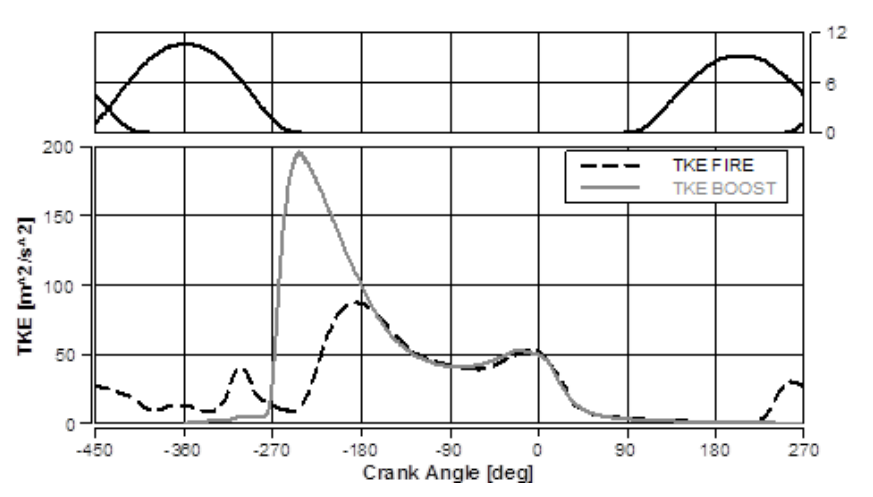

FIGURE 5: Calibration of 0-D turbulence kinetic energy (TKE) model by means of using 3-D CFD simulation data.

OBRÁZEK 5: Kalibrace 0-D modelu pro turbulentní kinetickou energii (TKE) při použití dat z 3-D CFD simulace.

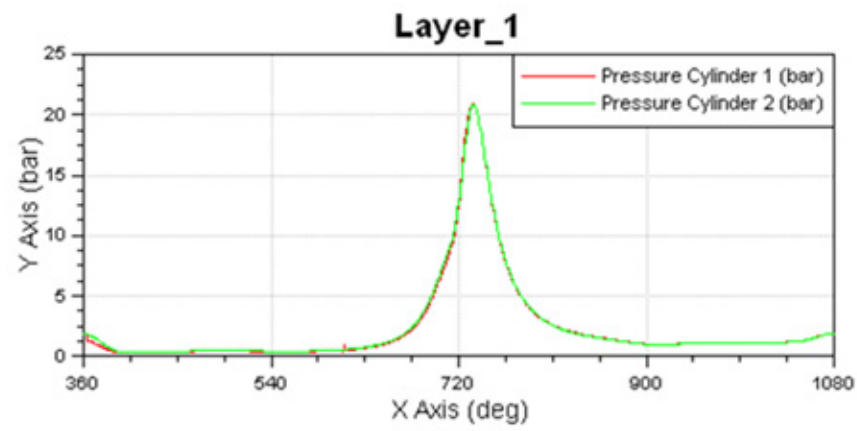

Layer_2

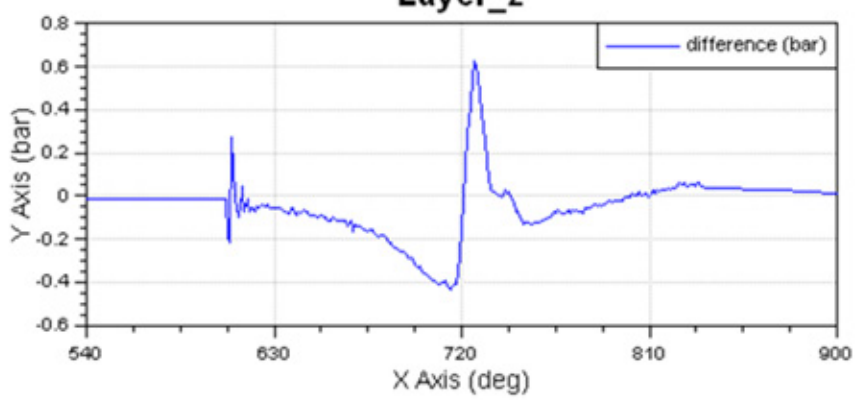

Layer_3

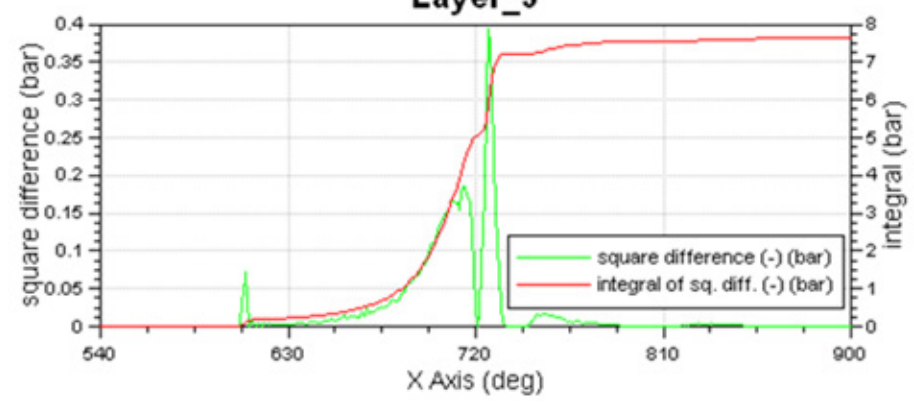

\subsection{INDIVIDUAL CYCLE CALIBRATION}

The text in the subsection above describes standard calibration task to match 0-D/1-D CFD model prediction with average engine cycle based on reference data. However, as every cycle is different (due to CCV), theoretically such task has to be performed for each individual cycle. It is well-known fact that 0-D/1-D ICE model calibration is time demanding task while a lot of model constants/parameters need to be determined. It is clear that many engine model parameters are independent of CCV, hence there is actually no need to perform the general calibration procedure (described in the previous subsection) for every individual cycle. It was verified that perturbation of certain combustion model parameters is sufficient to model CCV phenomenon. This statement is also confirmed by analysis of

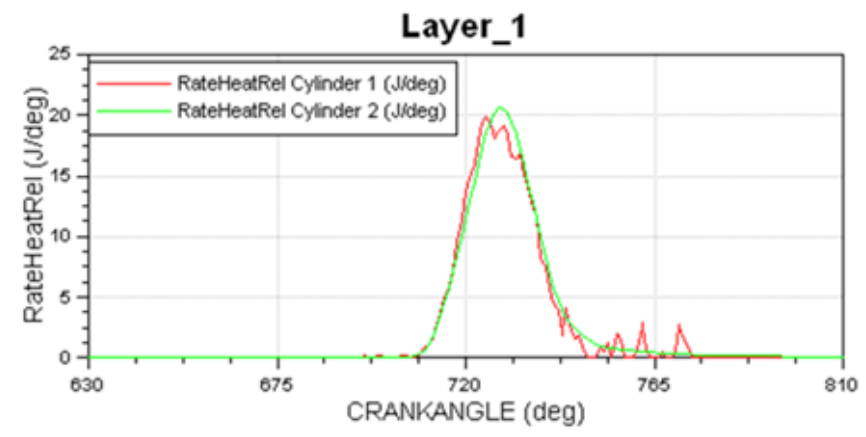

Layer_2

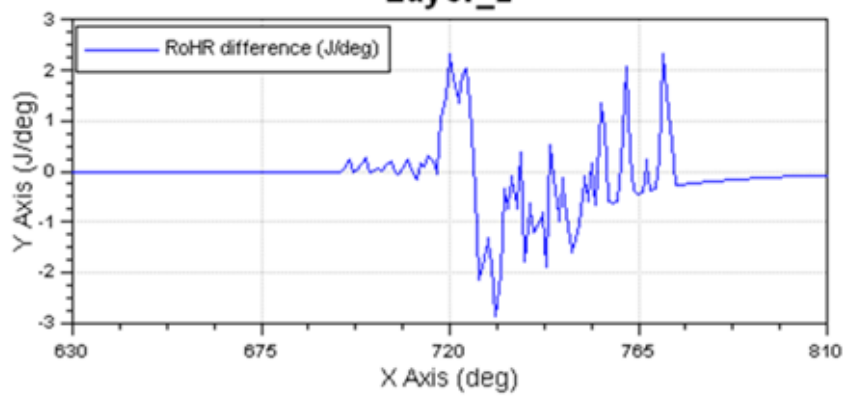

Layer_3

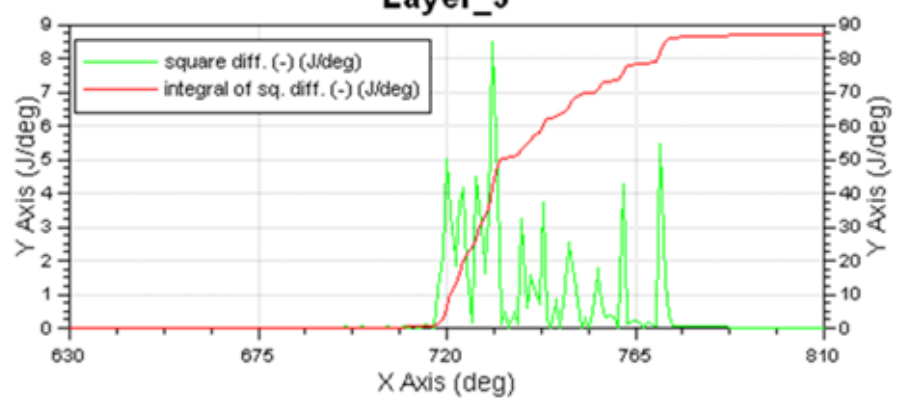

FIGURE 6: Example of in-cylinder pressure matching result using genetic algorithm - left figures correspond to in-cylinder pressure levels while right ones deal with ROHR; top row compares reference data (red curve) with prediction of 0-D combustion model (green curve); middle one concerns the difference between reference data and prediction; bottom one shows integral quadratic error value (red curve).

OBRÁzEK 6: Příklad použití genetického algoritmu pro kalibrace průběhu tlaku ve válci - obrázky vlevo odpovídají tlakům ve válci zatímco obrázky vpravo souvisí s vývinem tepla (ROHR); horní řada srovnává referenční data (červená křivka) s predikcí 0-D modelu hoření (zelená křivka); prostřední řada se týká rozdílu mezi referenčními daty a predikcí; spodní řada ukazuje integrální kvadratickou odchylku (červená křivka). 
Bozza_Cls

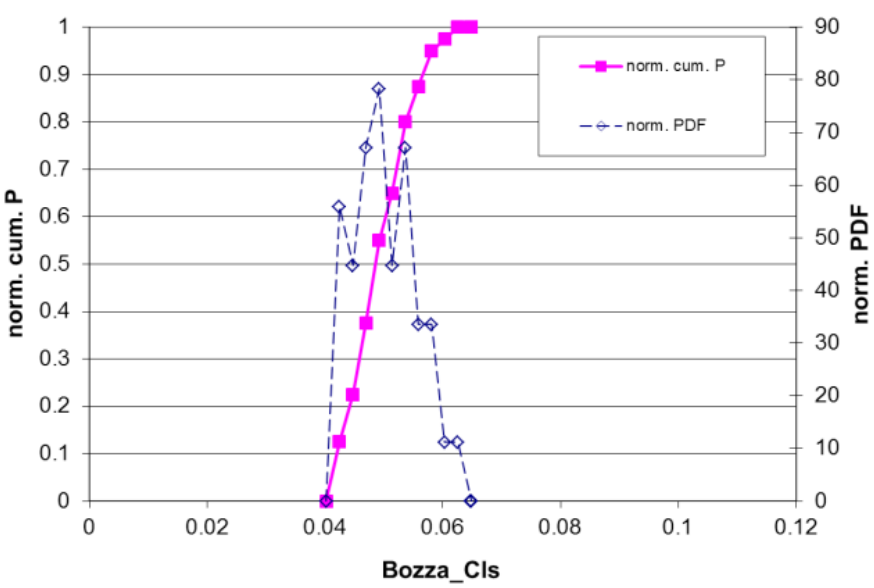

fract_ign_rad

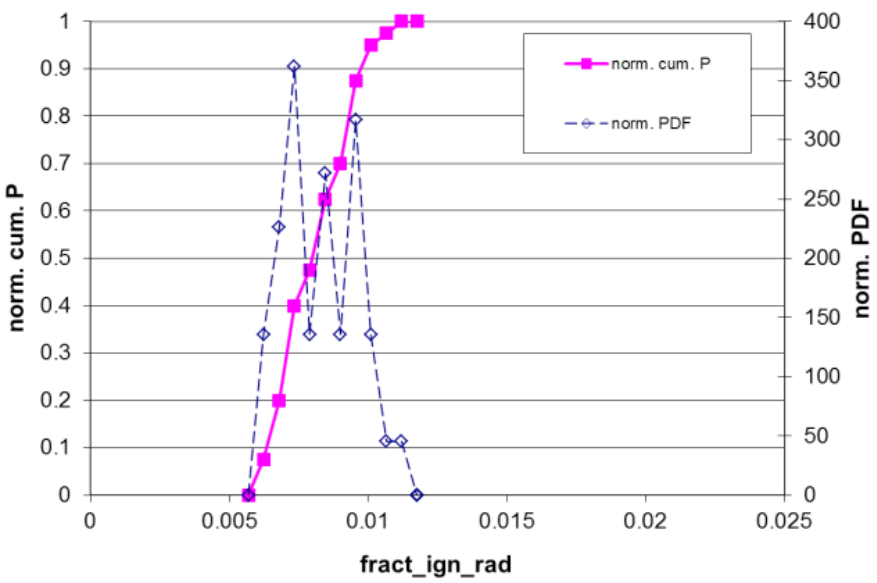

fract_mf_wall

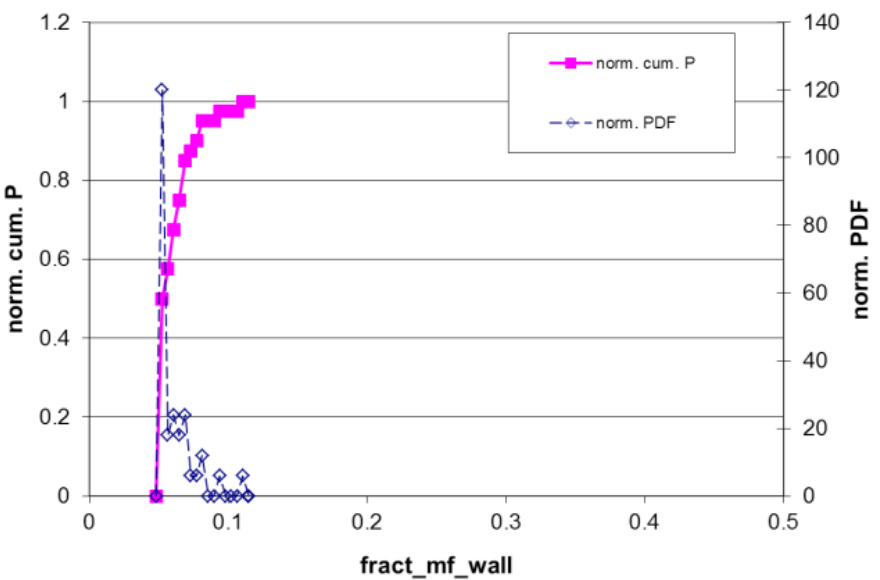

Bozza_Cls

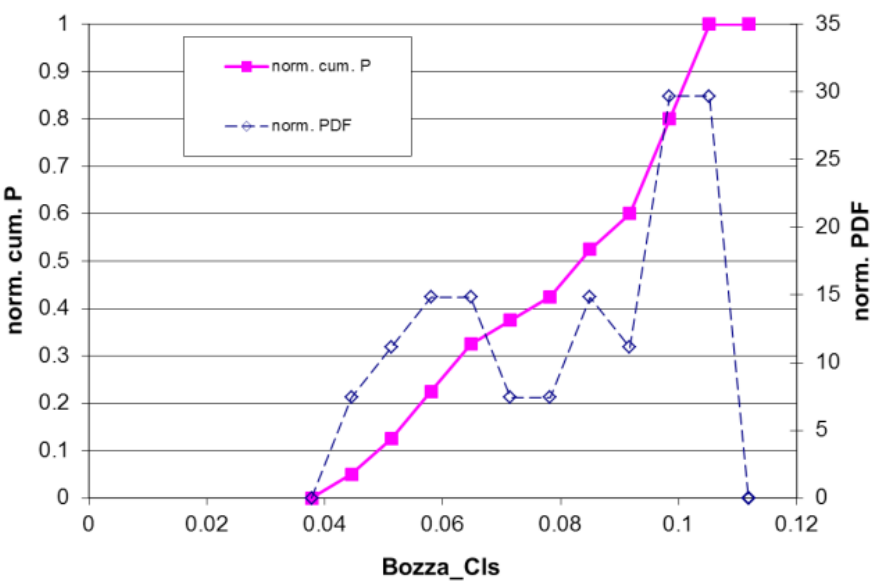

fract_ign_rad

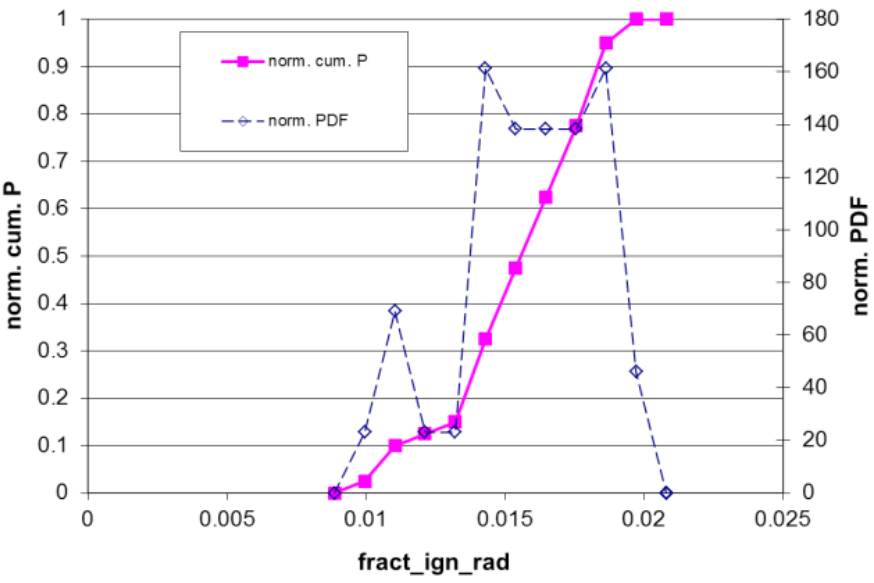

fract_mf_wall

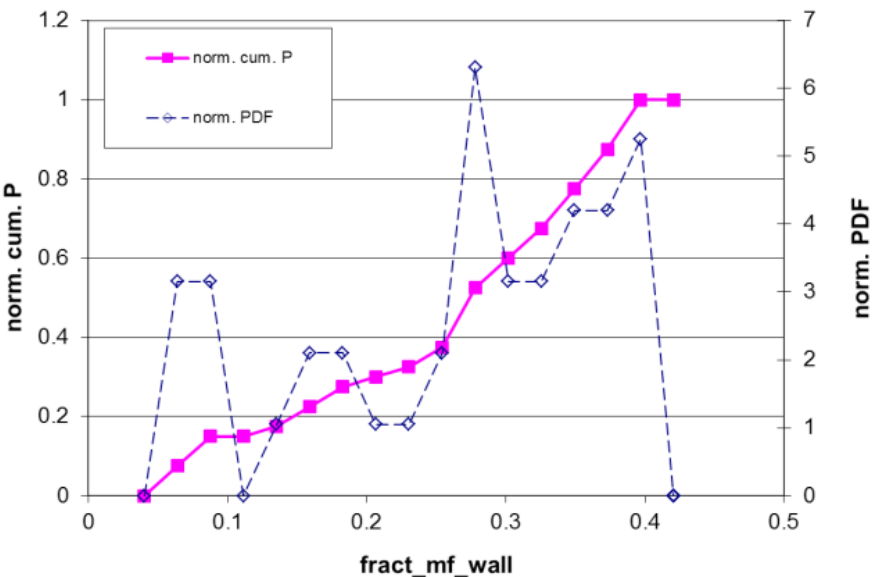

FIGURE 7: Comparison of combustion model statistics - the left column represents stable operating point (LP 2504) while the right one deals with unstable operating point (LP 2735); blue curve corresponds to PDF while the magenta one represents cumulative probability.

OBRÁZEK 7: Porovnání statistických údajů modelu hoření - levý sloupec representuje stabilní pracovní bod (LP 2504) zatímco pravý sloupec ukazuje nestabilní pracovní bod (LP 2735); modrá křivka odpovídá hustotě pravděpodobnosti kdežto fialová křivka reprezentuje kumulativní pravděpodobnost. 
detailed LES 3-D CFD data when many consecutive cycles were calculated. Hence, individual cycle matching is based on varying of selected combustion model parameters only while all other remaining model constants/parameters are fixed (their values were determined when calibration of the whole engine model was performed while considering average cycle - c.f. Figure 4). More detailed description of individual cycle matching procedure can be found in $[9,10]$.

The matching itself was achieved by application of optimization (genetic algorithm) - an automatic procedure was necessary due to high amount of data which had to be processed. The optimization consists in finding such values of the combustion model to minimize the difference between reference and predicted in-cylinder pressure (only high pressure phase of ICE cycle was considered, i.e., all valves are closed). The quality of automatic matching procedure can be estimated from Figure 6 . The matching procedure has to be performed for all measured individual cycles (typically 100 or more) while considering all operating points from Table 2.

It was already mentioned above that variation of combustion model parameters are supposed to be sufficient when modeling $\mathrm{CCV}$ of single-cylinder $\mathrm{SI}$ engine. This means that when performing matching procedure, all model parameters were fixed with the exception of selected parameters of the fractal combustion model (details can be found in [9]). Generally speaking, each combustion model requires different parameters to be varied to model CCV. To determine which parameters were to be varied, a sensitivity study (of many parameters) was performed. After analyzing the results, it was decided that three parameters are sufficient.

The parameters were selected in order to emphasize the individual physical mechanisms of the combustion process, i.e. turbulence, ignition process, and combustion. This would allow identifying physical effects and their interrelations by a statistical analysis of the parameter distributions and their cross-correlations. For the selection of appropriate parameters, sensitivity analyses were performed. For the turbulence model, the turbulence length scale parameter (labeled 'Bozza_Cls') was selected as it controls turbulence intensity, hence combustion speed. Higher values lead to faster combustion. Second, 'ignition delay' parameter (labeled 'fract_ign_rad') is selected, as it controls the delay between ignition and start of combustion ('visible' ROHR). Higher value causes longer 'ignition delay' and it corresponds to slower process of early flame kernel development. The flamefront driven combustion process is modeled on a sound physical basis (fractal combustion model - c.f. [9]). Therefore it does not include appropriate empirical tuning parameters. What regards the combustion progression, the main simplification of the 0-D approach is the simplified representation of the combustion chamber geometry. The target engine in particular has quite complex chamber geometry due to the characteristic piston bowl for the direct injection combustion system. Therefore, the wall-combustion mass fraction (labeled 'fract_mf_wall') was selected as the third parameter. This enables to shape ROHR curve, especially in the late phase of combustion process.

\subsection{STATISTICAL ANALYSIS}

Generally speaking, two different types of information were evaluated. First, probability distribution of each of the combustion model parameters was derived (c.f. Figure 7). Second, crosscorrelations (c.f. Figure 8) between any two parameters (of the fractal combustion model) were evaluated to understand the relations among them.

First information deals with probability distribution functions of the combustion model. They are shown in Figure 7. An obvious conclusion is that statistics of stable point (LP 2504) are closer to symmetrical distribution. Moreover the parameter range (horizontal axis) is narrower when compared with unstable operating point (LP 2735). It was verified that it is not necessary to process all available data (i.e., 100 consecutive cycles for each operating point) - it seems that only 70 consecutive cycles are needed to get almost identical statistics while using 40 consecutive cycles provides a reasonable estimate of all important statistical data.

There is also possibility to look at the correlation among the parameters of the combustion model - this is shown in Figure 8. It seems that when dealing with low CCV case (LP 2504), the correlation coefficients are relatively low - the combustion model parameters are almost statistically independent, hence they can be generated by random number generators independently. On the other hand, high CCV case (LP 2735) features strong correlation of certain parameters, most noticeably between 'Bozza_Cls' and 'fract_ign_rad', and also between 'fract_mf_ wall' and 'fract_ign_rad'. These parameters are definitely not statistically independent (hence they cannot be generated randomly).

The correlation interpretation from the physics point of view is the following. The correlation coefficient between 'Bozza_Cls' and 'fract_ign_rad' is positive, hence when the former one is increased it is very likely that the latter is increased as well. Increasing 'Bozza_Cls' means to increase turbulence kinetic energy (which also leads to faster combustion) in the cylinder while increasing 'fract_ign_rad' means to increase the 'delay' between spark discharge and start of combustion (identified by pressure increase when compared with motored regime). In other words, the positive correlation means that when incylinder turbulence is high (hence faster combustion), the actual combustion will start later - this may also suggest that high turbulence level slows initial phase of flame kernel 


\begin{tabular}{|c|c|c|c|c|c|c|c|}
\hline LP2690 (low CCV) & Bozza_Cls & fract_ign_rad & fract_mf_wall | & LP2735 (high CCV) & Bozza_Cls & fract_ign_rad & fract_mf_wall \\
\hline Bozza_Cls & 1.000 & 0.785 & 0.124 & Bozza_Cls & 1.000 & 0.572 & -0.173 \\
\hline fract_ign_rad & 0.785 & 1.000 & 0.378 & fract_ign_rad & 0.572 & 1.000 & -0.574 \\
\hline fract mf wall & 0.124 & 0.378 & 1.000 & fract mf wall & -0.173 & -0.574 & 1.000 \\
\hline
\end{tabular}

\begin{tabular}{|c|c|c|c|c|c|c|c|}
\hline LP2504 (low CCV) & Bozza_Cls & fract_ign_rad & fract_mf_wall & LP2610 (high CCV) & Bozza_Cls & fract_ign_rad & fract_mf_wall \\
\hline Bozza_Cls & 1.000 & 0.220 & -0.207 & Bozza_Cls & 1.000 & 0.519 & -0.578 \\
\hline fract_ign_rad & 0.220 & 1.000 & -0.102 & fract_ign_rad & 0.519 & 1.000 & -0.537 \\
\hline fract mf wall & -0.207 & -0.102 & 1.000 & fract mf wall & -0.578 & -0.537 & 1.000 \\
\hline
\end{tabular}

\begin{tabular}{|c|c|c|c|c|c|c|c|}
\hline LP2290 (low CCV) & Bozza_Cls & fract_ign_rad & fract_mf_wall & LP2299 (high CCV) & Bozza_Cls & fract_ign_rad & fract_mf_wall \\
\hline Bozza_Cls & 1.000 & 0.453 & -0.246 & Bozza_Cls & 1.000 & 0.543 & -0.485 \\
\hline fract_ign_rad & 0.453 & 1.000 & 0.000 & fract_ign_rad & 0.543 & 1.000 & -0.463 \\
\hline fract mf wall & -0.246 & 0.000 & 1.000 & fract mf wall & -0.485 & -0.463 & 1.000 \\
\hline
\end{tabular}

FIGURE 8: Correlation coefficients among considered parameters of the combustion model - the left column corresponds to stable regime (low CCV) while the right one represents unstable operation (high (CV); more details regarding operating points can be found in Table 2; each number (in the table) represents the correlation coefficient between selected 2 parameters (their label is printed in the 1st row/column); operating point label is printed using red color (top left in each table).

OBRÁZEK 8: Korelační koeficienty mezi uvažovanými parametry modelu hoření - levý sloupec odpovídá stabilním režimům (nízká mezicyklová variabilita) zatímco pravý sloupec reprezentuje nestabilní chod (vysoká mezicyklová variabilita); více informací k pracovním bodủm lze nalézt v Tabulce 2; každé číslo ( $v$ tabulce) odpovídá korelačnímu koeficientu mezi vybranými 2 parametry (jejich název je uveden v 1. řádku/sloupci); název pracovního bodu je uveden červeně (horní levý roh v každé tabulce).

development. The negative correlation between 'fract_ign_rad' and 'fract_mf_wall' means that when combustion starts later, the flame is constrained by the wall later in terms of amount of burnt fuel fraction. However, the influence of the parameter 'fract_mf_wall' on combustion progress is not straightforward - the higher value leads to the fact that more fuel is burned in 'wall-combustion mode' (c.f. [9] for more details), however it does not necessary mean that it burns slower (when compared with the ideal case when flame is not limited/constrained by wall presence). Moreover, this parameter influences only the late phase of the combustion process. Hence, the overall effect of the parameter 'fract_mf_wall' is not completely obvious. It seems that very low values lead to surprisingly slow burning during very late phase of combustion process ( $>85 \%$ burned fuel fraction).

Especially the correlation between turbulence ('Bozza_Cls') and 'ignition delay' ('fract_ign_rad') is important. It seems that turbulence causes complex interactions in the cylinder - it slows the early flame kernel development phase (i.e., increasing 'ignition delay'). However when there is a stable initial flame, it burns faster (due to higher flame propagation speed which is manly driven by turbulence level). This conclusion is yet to be verified by detailed 3-D CFD calculations using LES approach. The other significant cross-correlation (between 'fract_ign_rad' and 'fract_mf_wall') is present for unstable operating points only and it is seems to have important effect as well - it influences the later phases of combustion process. Low values, which are associated with higher turbulence and slower early flame kernel development (due to negative correlation coefficient - c.f. Figure 8), lead to slow burning during late combustion phase, hence compensating the effect of higher turbulence (i.e., faster combustion). Detailed analysis of the data suggests (c.f. Figure 11) that the overall effect in terms of combustion progress is not changed dramatically - if the combustion is delayed (due slow flame kernel development), it remains delayed all the way through. More details can be found in section Discussion of Results.

Final comment concerns correlations of stable operating points (left column in Figure 8). They exhibit relatively large spread of values (especially the one between 'Bozza_Cls' and 'fract_ign_ $\mathrm{rad}^{\prime}$ ). However, as the PDFs are relatively narrow (left column in Figure 7), the actual values of the parameters do not change significantly, hence their practical influence on in-cylinder pressure pattern is relatively low. This statement is confirmed by the fact that imposed CCV run based on random numbers only (i.e., respecting PDFs while ignoring correlations from Figure 8) leads to good match between the reference data and the simulation in 0-D/1-D tool. More details can be found in [9].

\subsection{IMPOSING STATISTICS IN 0-D/1-D SW TOOLS}

Once the statistics are known, they can be imposed into the $0-D / 1-D$ tool. The results regarding individual cycles can be imposed directly (hence, forcing individual cycles as they were measured), however this approach would not bring any new 
information. Moreover, it actually does not require any statistical data, hence there is no general methodology in it. That is why it was decided to impose CCV based on random numbers and statistical information obtained from evaluation of reference data (described above). Such approach allows testing the influence of different parameters, hence it enables to obtain additional knowledge regarding CCV phenomenon. It has to be stressed that the 0-D/1-D tool cannot predict the CCV phenomenon itself - this information has to be supplied by reference data (either experiments or 3-D CFD simulations).

From a technical point of view, the calibrated 0-D/1-D model was amended by the special object (Formula Interpreter) which allows modification of certain parameters during a simulation run. The object enables to add a user code (based on ANSI C programming) which is useful as almost any mathematical manipulation is possible.

When running the simulation while imposing CCV, the following procedure is employed. Initially constant parameters of the combustion model (based on average cycle) are imposed to reach certain level of convergence (cca 80 cycles). After that the user code is activated to impose CCV of the combustion model parameters. It was verified that this approach works well and the quality of results depends on the way of imposing statistical information.
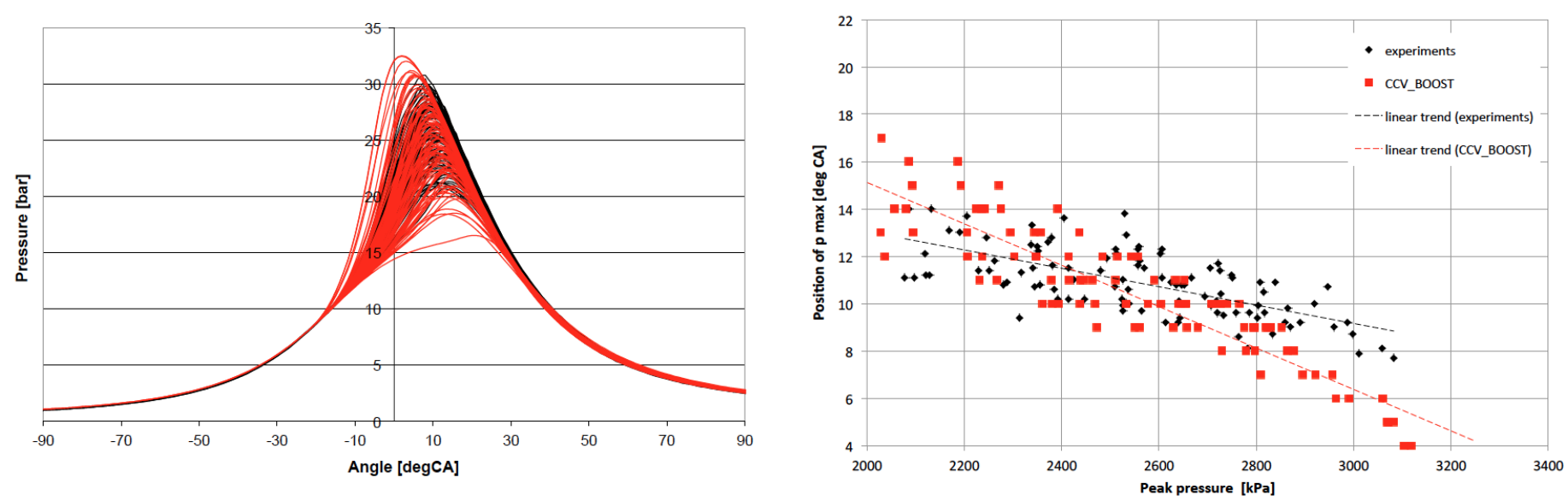

FIGURE 9: Comparison of reference data (black color) with predicted ones in 0-D/1-D SW tool (red color) in the case of unstable operating point (LP 2735) while PDFs are taken into account only (no cross-correlations considered) - left figure represents in-cylinder pressure traces, right figure shows crank angle position and the value of maximum in-cylinder pressure.

OBRÁZEK 9: Porovnání referenčních dat (černá barva) s predikcí v 0-D/1-D SW nástroji (červená barva) pro prípad nestabilního pracovního bodu (LP 2735) zatímco jsou uvažovány pouze hustoty pravděpodobnosti (nejsou uvažovány vzájemné korelace) - levý obrázek reprezentuje průběhy tlaku ve válci, pravý obrázek ukazuje úhlovou pozici výskytu maximálního tlaku ve válci.
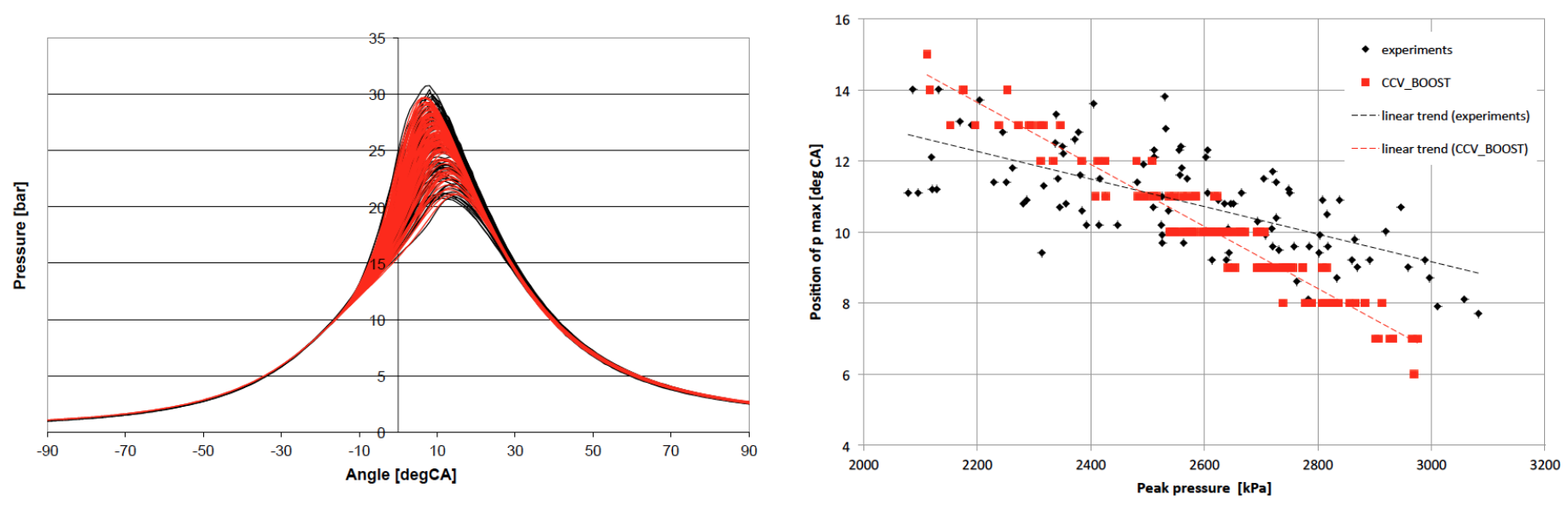

FIGURE X9X: Comparison of reference data (black color) with predicted ones in 0-D/1-D SW tool (red color) in the case of unstable operating point (LP 2735) while PDFs are taken into account including complex cross-correlations - left figure represents in-cylinder pressure traces, right figure shows crank angle position and the value of maximum in-cylinder pressure.

OBRÁZEK X9X: Porovnání referenčních dat (černá barva) s predikcí v 0-D/1-D SW nástroji (červená barva) pro př́pad nestabilního pracovního bodu (LP 2735) zatímco jsou uvažovány hustoty pravděpodobnosti včetně komplexních vzájemných korelací - levý obrázek reprezentuje průběhy tlaku ve válci, pravý obrázek ukazuje úhlovou pozici výskytu maximálního tlaku ve válci. 
It is obvious that both PDFs (c.f. Figure 7) and cross-correlations (c.f. Figure 8) need to be taken into account to mimic the CCV properly. However it turned out to be a difficult task to achieve both. At the end an iterative procedure was developed which satisfies both PDFs and cross-correlations. The method is not described in detail as it is not important how the data were obtained - the important fact is that it is possible to generate the combustion model parameters using random numbers while satisfying both PDFs and cross-correlations. One important feature is to determine how many 'degrees of freedom' are needed to achieve satisfactory results - this issue is discussed below in the section Discussion of Results.

\section{COMPUTED CASES}

The results presented in this paper deal with the engine from Table 1 while concerning all operating points from Table 2 . As the reference data were available for all these operating points, the methodology (described above in the section Methodology of CCV Modelling in 0-D/1-D CFD SW Tool) was applied to all of them.

The data shown in the following section are the outputs of applied methodology to available reference data. The main target of the paper is to transfer CCV knowledge from the reference data to 0-D/1-D CFD SW tool. Hence, the simulation results (from 0-D/1-D CFD tool) are presented including their statistical analysis to allow for comparison with statistics of reference data.

Many important results from 0-D/1-D system simulation tools when applying the above-mentioned methodology are presented in $[9,10]$. However, the focus of these papers was slightly different. Moreover, additional information was extracted from the reference data and the methodology was applied to more ICE operating points - hence, more information is available for evaluation. The main goal of the following section is to verify that the methodology is capable of CCV knowledge transfer including important statistics. Hence, the main attention is paid to quality of calculated data (from 0-D/1-D CFD tool) from statistical point of view.

\section{DISCUSSION OF RESULTS}

This section deals with important results of imposed CCV simulation runs and their comparison with the reference data. The easiest approach is to satisfy PDFs (Figure 7) without considering any cross-correlation information (Figure 8). Such approach is satisfactory for operating points with low CCV as their cross-correlation coefficients are usually low (c.f. Figure 8). However, when this way is adopted for high CCV case, the simulation results are far from satisfactory - c.f. Figure 9. Spread of pressure traces is over-predicted and it could be shown that important statistics are not satisfied. When considering PDFs and single cross-correlation from Figure 8 (the most important one is typically the cross-correlation between 'Bozza_Cls' and 'fract_ign_rad'), certain improvement is achieved, however it is still not satisfactory (details can be found in [9]). Only when PDFs and all important cross-correlations are taken into account, then the outcome is a good correspondence between simulation and the reference data - c.f. Figure X9X. Moreover, other statistics also seem to be reasonably close to those of the reference data - c.f. Figure 10 and 11.

To generate data based on random numbers while satisfying both PDFs and cross-correlations is relatively complex task. An iterative method was developed (no details are presented here) which enables to satisfy that. From mathematical point of view, imposing cross-correlations is effectively a way to decrease the amount of 'degrees of freedom' of the problem. If PDFs are imposed only (Figure 9), three random numbers are needed. If both PDFs and cross-correlations are needed (Figure X9X), still three random numbers are needed, however only one of them determines important properties (the remaining two numbers are used for a 'supportive' role).

It is interesting to compare different phases of combustion process - this information can be easily obtained from simulation, however it is more demanding to do that using experimental data as some relatively sophisticated calculations are needed. The comparison of data from 0-D/1-D tool and the reference data is shown in Figure 10. The cycle independence is easily predicted in imposed CCV simulation run - this is an important observation as it clearly shows that there is no influence of preceding cycle on combustion parameters/properties of the next cycle. It is also important to capture properly statistics regarding combustion progress/duration with respect to time (crank angle) - this is usually the case (c.f. Figure 10, right column). Obviously this comparison is also influenced by the quality of combustion model matching - the authors believe that the data shown in the figures confirm reasonable quality of matching process, which was achieved by automatic optimization procedure, and that the statistics are captured relatively well.

The combustion progress history is plotted in Figure 11 while both the reference data and the data from imposed CCV run are presented. The curve pattern and the spread of values are very similar, hence it confirms the above-mentioned good quality of simulation results in terms of CCV properties. It is interesting to note that all simulation data (imposed CCV run) and the reference data of unstable operating point (LP 2735) show a pattern that if early part of combustion progress (5 or $10 \%$ of burned fuel) is delayed with respect to average cycle data, it remains delayed for the whole combustion phase - in other words: it is very unlikely that slow initial combustion phase will result in so fast combustion that the whole combustion process 
diference between 0.05 and 0 (total burnt fuel 0.05)

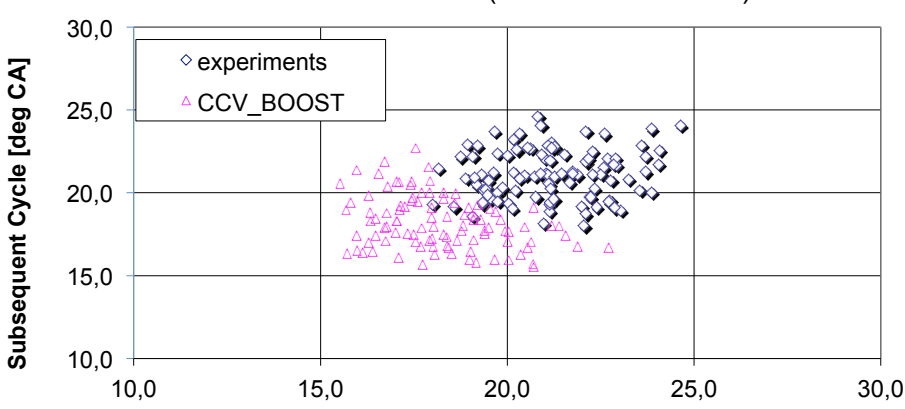

Preceding Cycle [deg CA]

diference between 0.5 and 0.1 (total burnt fuel 0.4 )

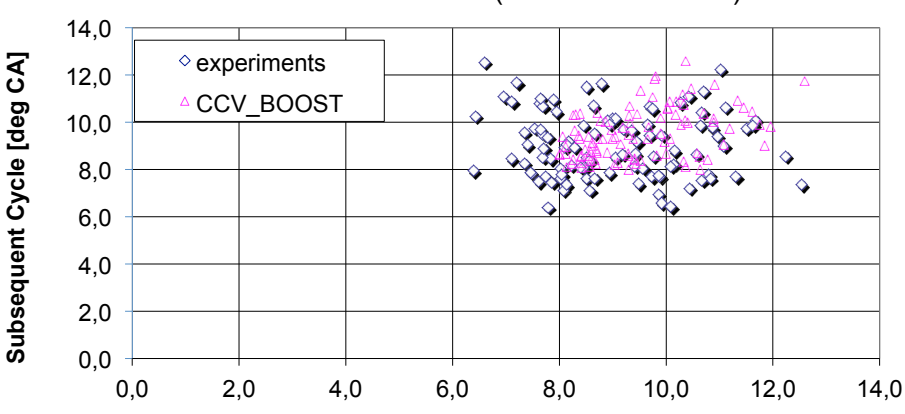

Preceding Cycle [deg CA]

diference between 0.9 and 0.5 (total burnt fuel 0.4 )

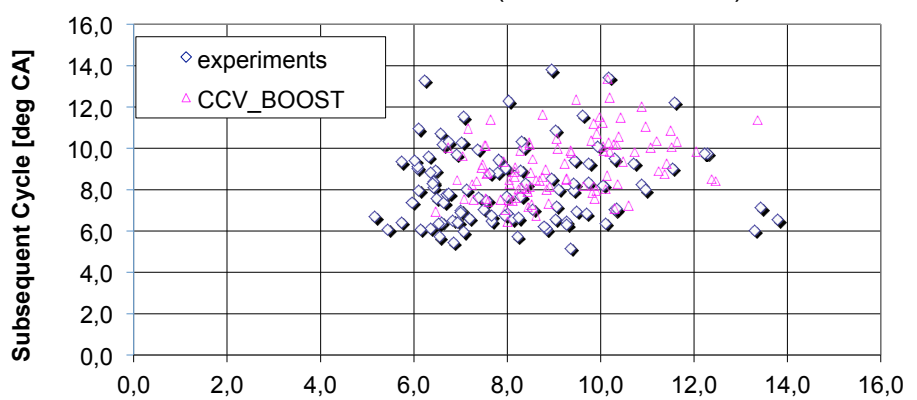

Preceding Cycle [deg CA] diference between 0.05 and 0 (total burnt fuel 0.05)

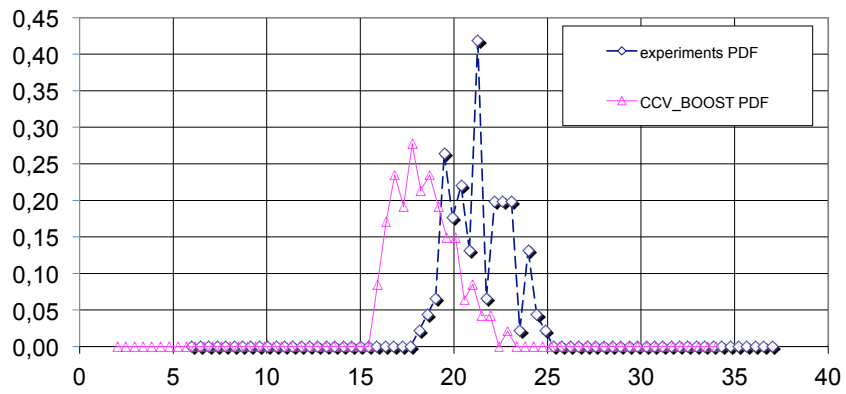

Angle Duration [deg CA]

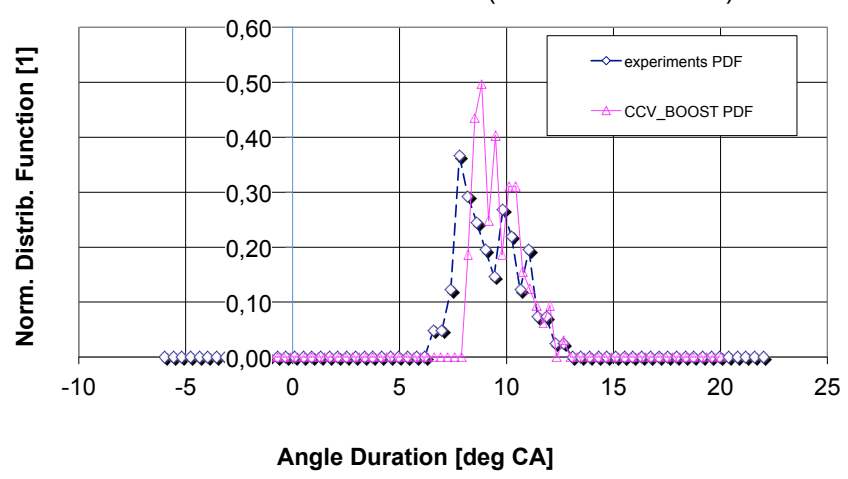

diference between 0.9 and 0.5 (total burnt fuel 0.4 )

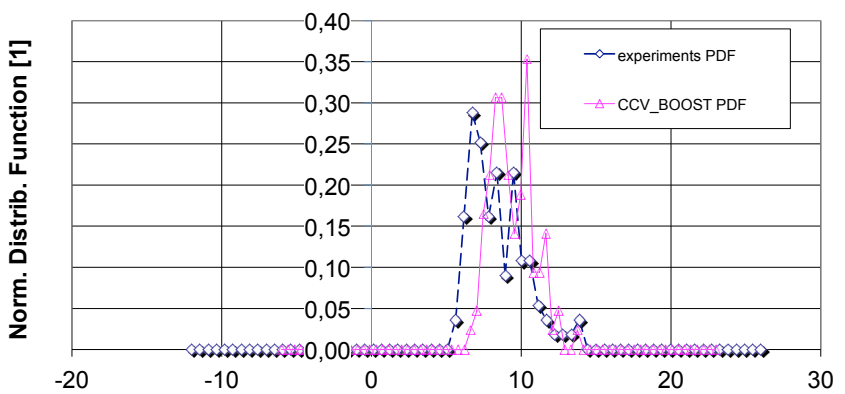

Angle Duration [deg CA]

FIGURE 10: Comparison between reference data (dark blue color) and imposed CCV simulation run (magenta color; pressure traces shown in Figure X9X) - statistical analysis of unstable operating point (LP 2735; complex cross-correlations taken into account) concerning different phases of combustion process (top row shows early phase, i.e., between $0 \%$ and $5 \%$ of mass burnt fuel; middle row presents the phase between $10 \%$ and $50 \%$ MBF; bottom row corresponds to phase between $50 \%$ and $90 \% \mathrm{MBF}$ ) - left column shows dependency between preceding cycle and subsequent one, right column corresponds to PDF; all crank angle information represents duration of the corresponding combustion phase.

OBRÁZEK 10: Porovnání mezi referenčními daty (tmavě modrá barva) a simulací s vnucenou mezicyklovou variabilitou (fialová barva; průběh tlaku je ukázán na Obrázku X9X) - statistická analýza pro nestabilní pracovní bod (LP 2735; komplexní vzájemné korelace brány v úvahu) při uvažování různých fází procesu hoření (horní řada ukazuje úvodní fázi, tj. mezi $0 \%$ až $5 \%$ spálené hmotnosti paliva; střední řada reprezentuje fázi mezi $10 \%$ až 50\% spáleného paliva; dolní řada odpovídá fázi 50\% až 90\% spáleného paliva) - levý sloupec ukazuje závislost mezi předcházejícím a následujícím cyklem, pravý sloupec odpovídá hustotě pravděpodobnosti; všechny úhlové údaje reprezentují trvání příslušné fáze hoření. 
LP 2504 - reference data:

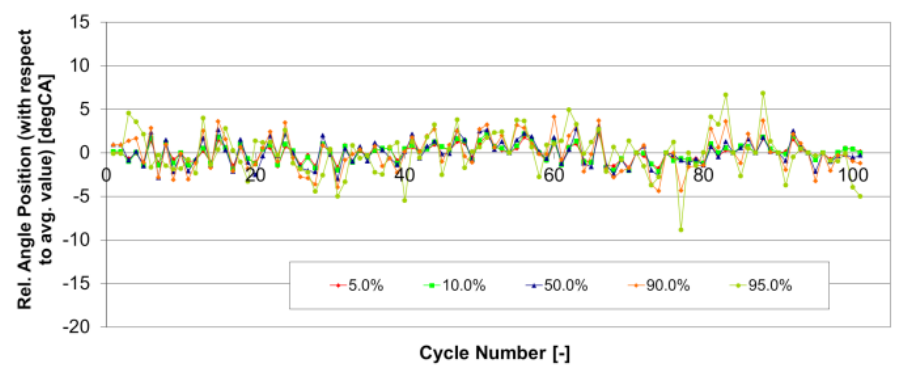

LP 2504 - data from 0-D/1-D SW tool after imposing CCV statistics from Figure 7 and 8:

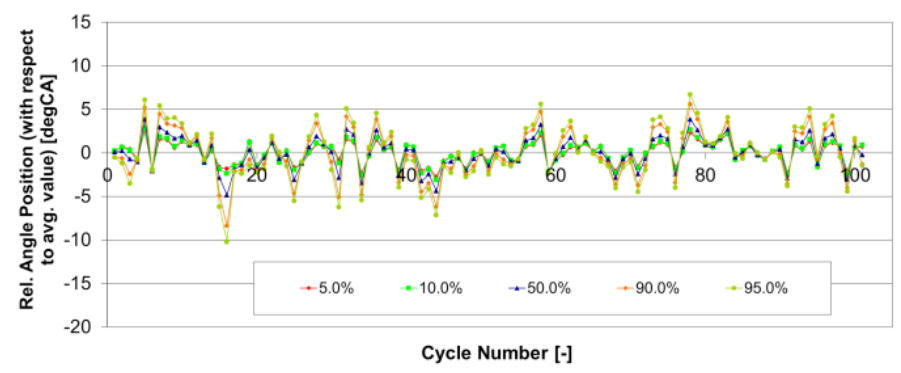

LP 2735 - reference data:

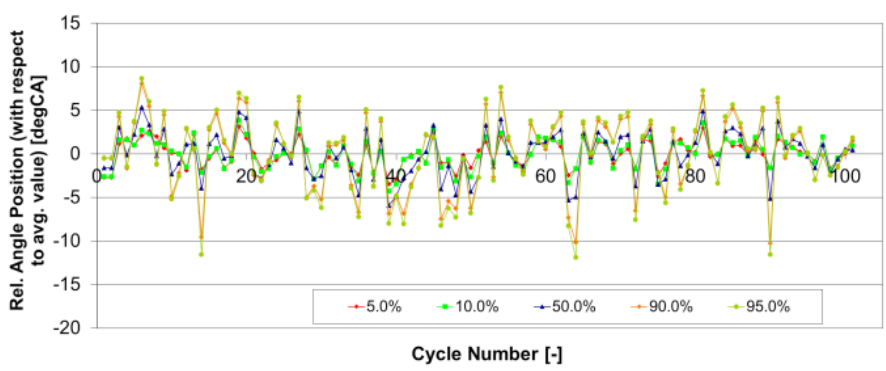

LP 2735 - data from 0-D/1-D SW tool after imposing CCV statistics from Figure 7 and 8:

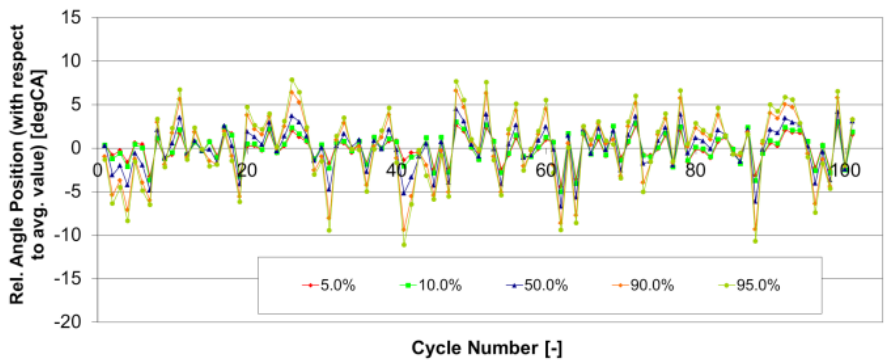

FIGURE 11: Comparison of reference data with predicted data in terms of relative angle position (with respect to average value) of combustion progress variable (labeling of operating points corresponds to Table 2).

OBRÁZEK 11: Porovnání mezi referenčními daty a simulací z hlediska relativní úhlové pozice (vzhledem k průměrné hodnotě) parametru, který popisuje časový vývoj hoření (označení pracovních bodů odpovídá Tabulce 2).

will end up earlier when compared with average data. Moreover, the trend is that slow initial combustion phase is likely to result in such combustion during later phases, that the difference between instantaneous value (of combustion progress variable) and the average one is not decreasing (usually it is slightly increasing). On the other hand, the reference data of stable operating point (LP 2504; top left subfigure in Figure 11) looks a bit different - it seems that the combustion progress variable is less organized (i.e., more random). However, the difference when compared with imposed CCV run (bottom left subfigure in Figure 11) is relatively small.

The data from Figure 8 and 11 clearly confirm that unstable operating points are more organized (less random) in terms of statistical parameters. Higher spread of important parameters (c.f. Figure 10) is compensated by stronger cross-correlations, hence the overall effect is higher CCV of in-cylinder pressure traces while they do not exhibit random effects (curve crossing of each other - this would happen when extreme values of combustion model parameters are combined randomly).

Although only 6 engine operating points were analyzed in detail (c.f. Table 2), it is interesting to get the information regarding possible dependencies of combustion model parameters, which were used for CCV modeling, and typical engine operating parameters. Such information is plotted in Figure 12. The most important information concerns average value of those parameters and their standard deviation. These 2 values can provide rough estimate of what happens with the PDF of such combustion model parameter - change of average value represents PDF shift while increase of standard deviation suggests PDF range widening. Regarding the turbulence parameter ('Bozza_Cls'), its average value increases with engine speed (this was to be expected), valve overlap and EGR while it decreases with IMEP. The same applies to standard deviation of that parameter. Concerning 'ignition delay', there are 2 significant dependencies - positive correlation with engine speed and negative correlation with IMEP. The same applies to standard deviation as well. Dealing with wall-combustion influence, it seems to increase with valve overlap and EGR. Again, the same applies to standard deviation. The last subfigure (bottom right one) in Figure 12 shows the same dependencies while concerning cross-correlations between any 2 parameters. Although there seems to be strong dependencies, they should not be overestimated as they are based on 6 operating points only when 3 of them can be regarded as stable ones (low CCV) while the other ones are unstable ones (high CCV). Much more data (in terms of the amount of engine operating points while considering different engine designs/types) need to be processed before any general conclusions can be drawn. However, it seems 
Bozza_Cls:

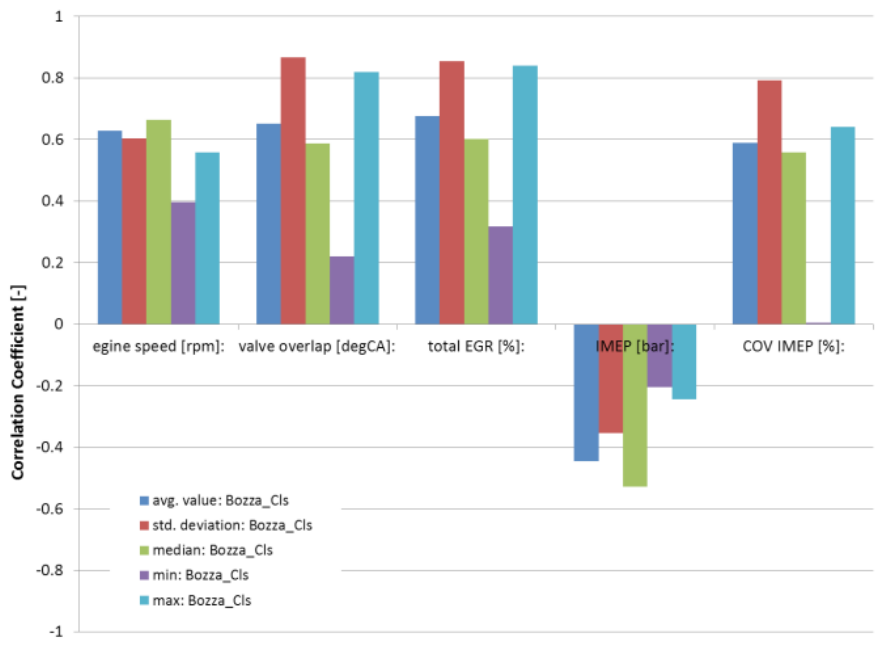

fract_mf_wall:

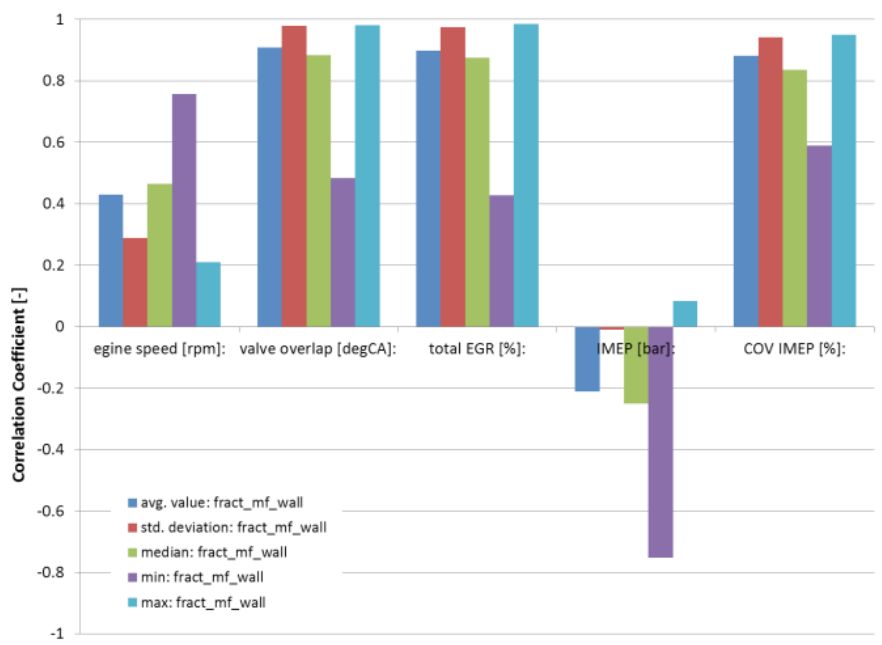

fract_ign_rad:

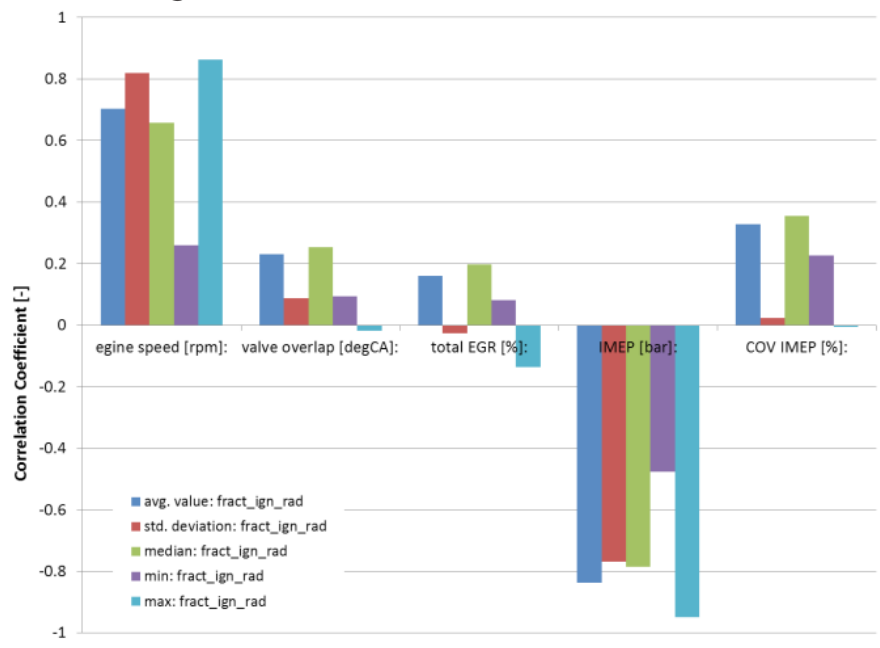

cross-correlations:

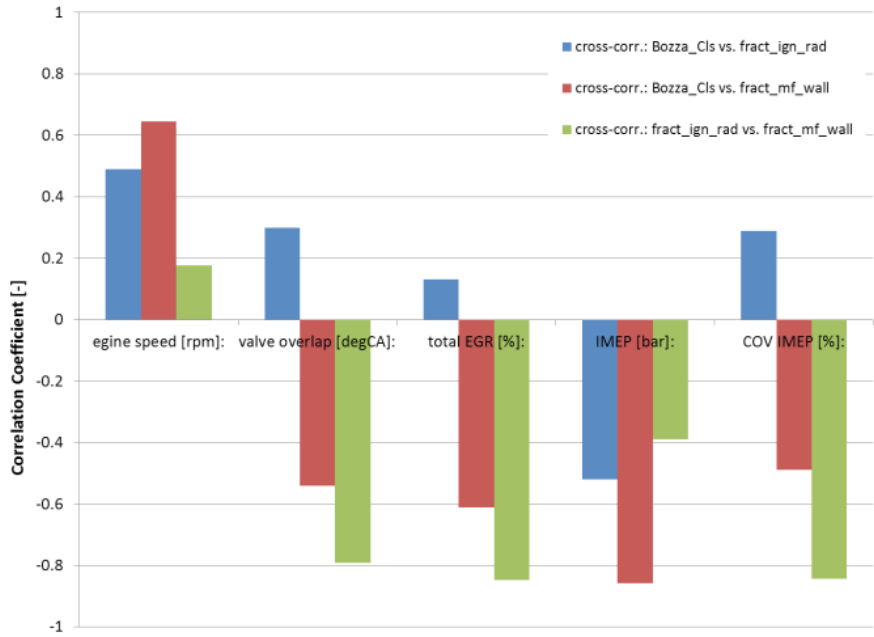

FIGURE 12: Dependence of combustion model statistical parameters on engine operating conditions - the plotted value is correlation coefficient between considered parameter (label is in legend) and engine operating parameters (labels are plotted on X-axis); considered engine operating points correspond to Table 2 .

OBRÁZEK 12: Závislost statistických parametrů modelu hoření na pracovních podmínkách motoru - zobrazená hodnota je korelační koeficient mezi uvažovaným parametrem (název je v legendě) a pracovními parametry motoru (názvy jsou na ose X); uvažované pracovní body odpovídají Tabulce 2.

that the combination of high EGR and high valve overlap leads to significantly wider PDFs of turbulence parameter ('Bozza_Cls') and wall-combustion parameter ('fract_mf_wall') and average values of those 2 parameters are increased as well. On the other hand, 'ignition delay' parameter ('fract_ign_rad') depends mainly on engine speed and IMEP.

\section{CONCLUSION}

The presented work deals with knowledge transfer in terms of CCV from reference data (either experimental data or 3-D (FD simulation results) into system simulation SW tools (based 0-D/1-D CFD approach). The proposed methodology is based statistical approach. The CCV information has to be imposed into 0-D/1-D CFD tool as it cannot predict the CCV phenomenon, hence the information regarding $\mathrm{CCV}$ has to be provided from other sources.

The main goal of the paper is to verify/evaluate the potential of the proposed methodology in terms of CCV knowledge transfer. Hence, the main focus is the quality of results which were achieved by imposed CCV runs in system simulation tool. All available information suggests that it is sufficient to perturb parameters of a combustion model to mimic CCV phenomenon properly. This statement is in-line with expectations as the target engine is a single-cylinder research engine. Hence,

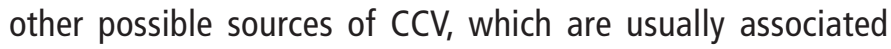
with multi-cylinder configuration of ICE, are not present here. 
Selection of suitable parameters of combustion model for this purpose strongly depends on applied combustion model itself. Regarding the example presented in this paper, the fractal combustion model was considered.

From mathematical point of view (regarding applied combustion model), it is necessary to have the ability to modify combustion speed (this is achieved by turbulence length scale, as it controls turbulence intensity which directly influences turbulent flame speed), to be able to shift ROHR curve (this is achieved by 'ignition delay' parameter, which controls the time between ignition discharge and actual start of burning). Finally, it is also needed to control the shape of ROHR curve, which might be achieved by wall-flame parameter. Experience shows that both turbulence length scale and 'ignition delay' parameter are important while wall-flame parameter is suitable for finetuning of the model (however it cannot be neglected). Hence, perturbation of 3 parameters is needed to model CCV.

There is a need to calibrate each individual engine cycle (at least 40 cycles are needed to obtain reasonable statistics) to create PDFs of all important parameters in terms of CCV - this causes that the method is relatively slow. Moreover, it was verified that PDFs of all considered combustion model parameters may not be sufficient to model properly the CCV phenomenon. Cross-correlations (among those parameters) are also important - in some cases, the cross-correlations are actually more important than PDFs. Hence, it is necessary to take into account all available statistical information. It was surprisingly difficult to impose both PDFs and crosscorrelations simultaneously - iterative method was developed to achieve that. Concerning the statistics, there is no influence of preceding cycles - this statement is also verified by the reference data (experimental data and 3-D CFD simulations using LES approach) which suggest that global parameters may not be so important while the local values (which are strongly influenced by their history) are critical for turbulent flame development. This is also confirmed in [11].

Generally speaking, CCV cannot be modeled using random perturbations only (this is suggested in certain papers, however it is not true for the considered engine case). It was verified that most dominant factors (in terms of CCV modeling) are turbulence intensity and the delay between ignition timing and actual start of burning. This confirms the conclusions from other publications (both experimentally based and 3-D CFD simulation ones) that both turbulence properties and initial flame kernel development are the most critical factors regarding CCV. In the case of the target engine, these factors seem to be correlated - this is yet to be confirmed by 3-D CFD LES calculations while using detail model of ignition process. Regarding the main focus of the paper, which is the CCV knowledge transfer from the reference data into system simulation SW tools, the following can be stated. The reference data can be either experimental data, which are typically obtained when performing detailed ICE measurements, or multi-cycle 3-D CFD data, which are typically acquired by LES simulations. The proposed method can deal with both cases. However, it is obvious that much more detailed knowledge can be obtained from 3-D CFD simulations. On the other hand, it is recommended to have both data types as the LES calculations are not fully verified in terms of quantitative prediction quality (there are papers confirming good qualitative correspondence with experimental data and the LES approach is clearly improvement in terms of turbulence modeling in ICEs when compared with standard RANS approach). The methodology of CCV knowledge transfer is based on statistical approach. It was verified that the method works well when both PDFs and cross-correlations are transferred into system simulation tools. It should be stressed that these tools (i.e., system simulation SW tools based on 0-D/1-D CFD approach) cannot predict the CCV phenomenon as it is strongly related to local 3-D thermodynamic properties. Hence, the CCV has to be imposed into such tools.

Final comment concerns the influence of $\mathrm{CCV}$ on global/integral performance parameters of SI ICEs. Based on the data shown in this paper and supported by results from $[9,10]$, the following can be stated. The high CCV cases are typically related to high load at low engine speed or low load at low engine speed. The former one is associated with knocking phenomenon while the latter one is usually related to high internal EGR. If CCV can be completely removed (hence all instantaneous engine cycles correspond to average cycle), there is a potential to improve fuel consumption by up to $4 \%$ for passenger car naturally aspirated SI ICE at full load while up to $2 \%$ of fuel can be saved at low load operation. This is achieved by possibility to increase engine compression ratio. Hence, there is some non-negligible potential for improvement of ICE efficiency. However, the CCV phenomenon is strongly related to non-linear interaction of flame front propagation process with local turbulence. It is obvious that this can be hardly controlled on local level.

\section{ACKNOWLEDGEMENTS}

This research has been realized using the support of The Ministry of Education, Youth and Sports program NPU I (LO), project L01311: 'Development of Vehicle Centre of Sustainable Mobility'.

All the help has been gratefully appreciated. 
LIST OF NOTATIONS AND ABBREVIATIONS

$\begin{array}{ll}\text { CCV } & \text { Cycle-to-Cycle Variation(s) } \\ \text { CFD } & \text { Computational Fluid Dynamics } \\ \text { COV } & \text { Coefficient of Variation } \\ \text { DI } & \text { Direct Injection } \\ \text { EGR } & \text { Exhaust Gas Recirculation } \\ \text { IMEP } & \text { Indicated Mean Effective Pressure } \\ \text { ICE } & \text { Internal Combustion Engine } \\ \text { IVC } & \text { Intake Valve Closing } \\ \text { KE } & \text { Kinetic Energy } \\ \text { LES } & \text { Large Eddy Simulation } \\ \text { PDF } & \text { Probability Density Function } \\ \text { ROHR } & \text { Rate of Heat Release } \\ \text { SI } & \text { Spark Ignition } \\ \text { SW } & \text { Software } \\ \text { RANS } & \text { Reynolds Averaged Navier-Stokes (equation set) } \\ \text { TKE } & \text { Turbulence Kinetic Energy }\end{array}$

\section{REFERENCES}

[1] Bozza, F., Gimelli, A., Merola, S., and Vaglieco, B., (2005). Validation of a Fractal Combustion Model through Flame Imaging. SAE Technical Paper 2005-01-1120, doi:10.4271/2005-01-1120.

[2] Bozza, F., Fontana, G., Galloni, E., and Torella, E., (2007). 3D-1D Analyses of the Turbulent Flow Field, Burning Speed and Knock Occurrence in a Turbocharged SI Engine. SAE Technical Paper 2007-24-0029, doi:10.4271/2007-24-0029.

[3] North G.L. and Santavicca D.A., (1990). The Fractal Nature of Premixed Turbulent Flames. Comb. Science and Tech., Vol. 72, pp.215-232.

[4] Bozza, F., Gimelli, A., Senatore, A., and Caraceni, A., (2001). A Theoretical Comparison of Various VVA Systems for Performance and Emission Improvements of SI-Engines. SAE Technical Paper 2001-01-0670, doi:10.4271/2001-01-0670.
[5] Vitek, O., Macek, J., Tatschl, R., Pavlovic, Z. et al., (2012). LES Simulation of Direct Injection SI-Engine In-Cylinder Flow. SAE Technical Paper 2012-01-0138, doi:10.4271/2012-01-0138.

[6] Tatschl, R., Bogensperger, M., Pavlovic, Z., Priesching, P. et al., (2013). LES Simulation of Flame Propagation in a Direct-Injection SI-Engine to Identify the Causes of Cycle-to-Cycle Combustion Variations. SAE Technical Paper 2013-01-1084, doi:10.4271/2013-01-1084.

[7] Vermorel, O., Richard, S., Colin, O., Angelberger, C., Benkenida, A., Veynante, D., (2011). Multi-Cycle LES Simulations of Flow and Combustion in a PFI SI 4-Valve Production Engine. SAE Technical Paper 2011-01-0151, doi: 10.4271/2007-01-0151.

[8] Thobois, L., Rymer, G., Soulères, T., Poinsot, T., (2004). LargeEddy Simulation in IC Engine Geometries. SAE Technical Paper 2004-01-1854, doi:10.4271/2004-01-1854.

[9] Vitek, O., Macek, J., Poetsch, C., and Tatschl, R., (2013). Modeling Cycle-to-Cycle Variations in 0-D/1-D Simulation by Means of Combustion Model Parameter Perturbations based on Statistics of Cycle-Resolved Data. SAE Int. J. Engines 6(2):1075-1098, doi:10.4271/2013-01-1314.

[10] Poetsch, C., Schuemie, H., Ofner, H., Tatschl, R. et al., (2013). A Computational Study on the Impact of Cycleto-Cycle Combustion Fluctuations on Fuel Consumption and Knock in Steady-State and Drivecycle Operation. SAE Technical Paper 2013-24-0030, doi:10.4271/2013-24-0030.

[11] Abdi Aghdam, E., Burluka, A., Hattrell, T., Liu, K. et al., (2007). Study of Cyclic Variation in an SI Engine Using Quasi-Dimensional Combustion Model. SAE Technical Paper 2007-01-0939, 2007, doi: 10.4271/2007-01-0939

[12] AVL AST (2013). FIRE Manual v2013, AVL List GmbH, Graz.

[13] B00ST 2011SP1 [DVD]. AVL List GmbH, 2011. 